\title{
Multi-dimensional struggles in the greening of industry: A dialectic issue lifecycle model and case study
}

\author{
Caetano C.R. Penna*, Frank W. Geels \\ SPRU, Science and Technology Policy Research, Freeman Building, University of Sussex, Brighton, UK
}

\section{A R T I C L E I N F O}

\section{Article history:}

Received 20 December 2010

Received in revised form 1 July 2011

Accepted 28 September 2011

Available online 9 February 2012

\section{Keywords:}

Greening of Industry

Issue lifecycle

Industry regime

Corporate political strategy

American car industry

Air pollution

\begin{abstract}
A B S T R A C T
This paper aims to make two conceptual contributions to the greening of industry literature. Firstly, we propose that the greening process can be conceptualized as an issue lifecycle dynamics with multi-dimensional struggles between 'greening' pressures and industry response strategies. To capture the endogenous dynamics, we develop a Dialectic Issue LifeCycle model with five phases, which conceptualize how these struggles play out over time. Secondly, we propose that issue lifecycle dynamics are also influenced by (external) alignments with contextual field-level developments. This proposition accommodates the notion that industries not only face 'green' issues but also other relevant pressures. We apply the model to a historical case study: air pollution problems and responses from American automakers (1943-1985). The case study presents a good match with the first three phases of the model, but shows deviations in the fourth and fifth phase, which are due to: a) decreasing pressure from public opinion; b) limited spillovers from air pollution to consumer demand; c) rise of competing issues; and d) strong resistance from the car industry. The findings underline that the greening of industry cannot be fully understood by looking only at the focal issue (e.g. air pollution). Broader developments in industry and external contexts also need to be taken into account.
\end{abstract}

(c) 2012 Elsevier Inc. All rights reserved.

\section{Introduction}

The 'greening of industry' is an important topic, because industries not only contribute to environmental problems, but can also play a role in solving them. Academic thinking about this topic has changed substantially during the last four decades in terms of main disciplines, focus, strategic implications and level of analysis. We simplify and stylize this literature into three overlapping phases (Table 1). We briefly discuss these phases to position our contributions to the last phase.

In the 1970s and 1980s pollution problems in air, surface water and soil gave rise to environmental regulations. Economists conceptualized these regulations as imposing additional costs to firms, which should therefore be expected to employ 'resistant adaptation' strategies: they would only implement pollution control technologies and waste management techniques to comply with regulations [1].

The 1990s form the second phase, with business and management scholars making new contributions, e.g. via the Greening of Industry Network, created in 1991. These scholars changed the focus towards firms-in-industries and took a longer-term view on technical transformation and competitive dynamics [1,2]. They asked why and how firms and industries could be motivated to move beyond compliance strategies and towards proactive 'green' strategies. Two debates were central. Porter and Van der Linde [3], who advocated win-win solutions with environmental management systems, cleaner production process and reduced material use actually reducing costs, triggered a debate on 'does it pay to be green?'. This debate, which stays close to the economic

\footnotetext{
* Corresponding author.

E-mail addresses: c.penna@sussex.ac.uk (C.C.R. Penna), f.w.geels@sussex.ac.uk (F.W. Geels).
} 
Table 1

Schematic summary of changes in greening of industry literature.

\begin{tabular}{llll}
\hline & 1970s, 1980s & 1990s & Late 1990s-2010 \\
\hline Main discipline & Economics & Business and management & $\begin{array}{l}\text { Organization theory, innovation studies, } \\
\text { evolutionary economics, neo-institutional theory } \\
\text { Environmental innovation as longitudinal process, } \\
\text { influenced by political struggles, public debates, } \\
\text { economic considerations, technical capabilities. } \\
\text { Mocus }\end{array}$ \\
$\begin{array}{l}\text { Environmental innovation } \\
\text { increases costs }\end{array}$ & $\begin{array}{l}\text { Environmental innovation can create } \\
\text { competitive advantage } \\
\text { (win-win solutions). } \\
\text { Level of analysional strategic games }\end{array}$ \\
\hline
\end{tabular}

framing, is still ongoing $[4,5]$. The second debate was about the determinants of corporate greening, which gave rise to two research strands. The first strand identified lists of (static) factors [6-8], which range from external factors such as environmental policy, consumer demand and media attention to organizational factors such as leadership style, corporate ethics and resources (technical, financial, organizational). The second strand developed prescriptive phase models in which industrial firms moved from noncompliance to compliance to pro-active 'green' positions, depending on changes in CEO attitudes and socio-psychological characteristics $[1,9,10]$.

The last two research strands received criticisms in the late 1990s. The first strand was criticized for a "failure to attribute degrees of importance to the identified influences" [7] (p. 195). The second strand was criticized for: a) an internalistic focus on firms and CEO attitudes [11], b) adhering to a linear model with deterministic progression through stages [12], c) prescriptive advocacy and moralistic bias [13].

In the third phase, scholars began addressing interactions between industry-internal processes and external contexts [12,14]. To develop multi-dimensional understandings, scholars also began mobilizing insights from wider theoretical traditions such as evolutionary and institutional perspectives, organization theory and innovation studies $[2,12,15]$. Hoffman and Ventresca [16] proposed an organizational field approach which focuses on the "complex evolution of ideas, resources, social structures, and practices as organizational process that takes shape in broader, increasingly institutionally structured policy fields" (p. 2). The greening of industry was increasingly studied as a longitudinal process that involves corporate strategy, public debate and dialogue, political conflict as well as technical and economic dimensions. To address the political, cultural, economic, technical and business dimensions, Kallio and Nordberg [13] recognize that the greening of industry literature has moved towards "a more multiform theoretical base". They also contended that: "What is still clearly missing is synthetic research orientation and general models and theories that could be used for framing the "big picture' and the 'big questions' of corporate greening" (p. 446). This paper aims to fill that gap by addressing the following question: how can we understand the greening of industry as a longitudinal process with multiple interacting dimensions? To answer that question, we make two contributions. The first contribution is the development of a Dialectic Issue LifeCycle (DILC) model. This new model conceptualizes environmental problems (e.g. air pollution, climate change, acid rain) as social issues that emerge and develop over time. ${ }^{1}$ Building on issue lifecycle theory, we distinguish several phases to capture the longitudinal characteristic of greening processes. To conceptualize multi-dimensional interactions, we suggest that issue life cycles progress through struggles between industries and other field-level actors. As the issue progresses through subsequent phases, different actors become involved in the struggles. Because industries are the focal actor, we conceptualize these struggles as dialectical interactions between 'green' pressures and industry response strategies. The DILC-model conceptualizes how these struggles play out over time on cultural, political, economic, technological and business dimensions. The second contribution is based on the recognition that the green 'focal' issue is only one of the pressures an industry faces. To understand the greening of industry, it is not sufficient to analyse the internal drivers of issue lifecycles (i.e. the dialectic struggles and interactions). It is also crucial to analyse alignments between the issue life cycle and broader fieldlevel developments (other pressures and industry responses). To elaborate this point, we build on an existing triple embeddedness framework (TEF) of industries.

Our model has a processual focus and works within a sociological tradition that looks at actors, their perceptions, strategies, resources, moves and countermoves. Industries are seen as embedded in organizational fields, where they interact with government actors, critical exchange partners, intermediaries in the value chain, professional and trade associations, regulatory bodies, and organized public opinion [17]. Industries, which we simplify here to populations of firms and their branch organizations, share certain characteristics ('industry regime'), but differ in specific strategies. The paper pays less attention to other industry actors such as employees, shareholders, knowledge intensive business services, banks, distribution chains, test agencies etc. While our 'big picture' framework builds on the organizational field approach to include various external contexts of industries, it also incorporates endogenous strategies such as technological innovation, corporate strategy, and political activities. Our model suggests that it is the interaction between external pressures and endogenous response strategies that drives the evolution of 'green' issues.

\footnotetext{
${ }^{1}$ A social issue refers to a condition or state of affairs that certain actors perceive as undesirable or problematic. The meaning of issues is socially constructed [27]. Views on causes, responsibility, seriousness and solutions are contested and develop over time.
} 
To illustrate our model and contextual alignments, we apply it to a historical case study: air pollution (smog) and the American car industry (1943-1985). We also aim to use the case study to inductively enrich our model, in particular to elaborate the multidimensional strategies of industry actors and how they change over time as the issue lifecycle unfolds.

The paper is structured as follows. Section 2 describes our analytical model. Section 3 discusses case selection and data sources. Section 4 presents the case study. Section 5 tests and enriches the model by analysing the (mis)match with the case study (patternmatching). Section 6 draws conclusions and discusses broader implications. As a qualifier, we note that big picture theorising has drawbacks related to trade-offs between depth and breadth. Also our 40-year case study for an entire industry and organizational field means that some details have been sacrificed in order to highlight more general patterns and mechanisms.

\section{A dialectic issue lifecycle model of the greening of industry}

\subsection{A multi-dimensional view of industries}

Before discussing issue lifecycle theory, we present our view on industries, which we see as embedded in organizational fields (in line with recent greening of industry research). We use a recently developed triple embeddedness framework [18], which divides organizational fields into two environments: an (economic) task environment and an institutional environment [17]. The task environment includes actors that engage in economic transactions with the industry. In the task environment, firms face economic selection pressures from Porter's [19] five industry forces: rivalry from competitors, bargaining power of suppliers, bargaining power of buyers, new entrants, and technological substitutes.

In the institutional environment, which contains policy makers, the general public, and social movements, organizations compete for social fitness and legitimacy, which arise from conformity to cultural beliefs (e.g. public opinion), social values (and stakeholder pressures), and regulatory-political pressures. These institutional selection pressures influence the industry's 'license to operate'.

TEF also conceptualizes firms as embedded in 'industry regimes', which are industry-specific institutions that mediate their actions towards external environments. In this perspective industry regimes are seen as containing a semi-coherent set of deep structural elements [18]:

1) Capabilities and technical knowledge, which are crucial resources for operational processes and innovation activities ${ }^{2}$;

2) Identity and mission, which signal the industry's societal purpose and business domain;

3) Beliefs and cognitive frames, which mediate managerial interpretations of signals, opportunities, and pressures from external environments;

4) Regulations and other formal policies (e.g. taxes, subsidies, intellectual property laws, tariffs, R\&D programs) shape the industry's economic frame conditions.

Firms-in-an-industry draw on these regime elements [20] in their interactions with task and institutional environments. Industry actors employ various strategies to adjust to external pressures and to shape their environments, which are thus partly enacted:

a) Economic positioning strategies focus on the position of industries in the (economic) task environment [19].

b) Innovation/technology strategies aim to improve products and production processes.

c) Political strategies relate to government policies, and include lobbying, financial contributions to political parties, litigation, organized pressure strategies, information strategies and non-compliance strategies [21];

d) Socio-cultural strategies aim to influence public opinion, and include framing strategies, public relations, advertising and information campaigns [22].

Fig. 1 schematically represents the triple embeddedness of industries in two (external) environments and an industry regime. Existing industry regimes are stabilized by various lock-in mechanisms: a) technical capabilities can turn into core rigidities, which limit what firms can do; b) established beliefs may blind actors to developments outside their focus [23]; c) mission and identity are difficult to change because they refer to taken-for-granted beliefs that actors have about themselves and their role in society; d) regulatory institutions can create lock-in by providing incentives that facilitate actions in certain directions more than in other directions. The implication is that industry actors tend to resist changes that deviate too much from the existing regime template. This resistance also applies to 'green' issues, as we will discuss below.

\subsection{Towards a dialectic issue lifecycle model}

If we conceptualize environmental problems such as air pollution as 'issues', we can build on insights from the issue lifecycle literature to conceptualize the greening of industry. The early issue lifecycle literature developed stage models, in which issues emerge in civil society, spill over to politics, and lead to policies that are subsequently implemented. Buchholz [24], for instance, distinguished three stages: a) public opinion formation; b) public policy formulation; c) public policy implementation. Post [25]

\footnotetext{
${ }^{2}$ At the industry level, shared knowledge is often referred to as a technological regime [20].
} 


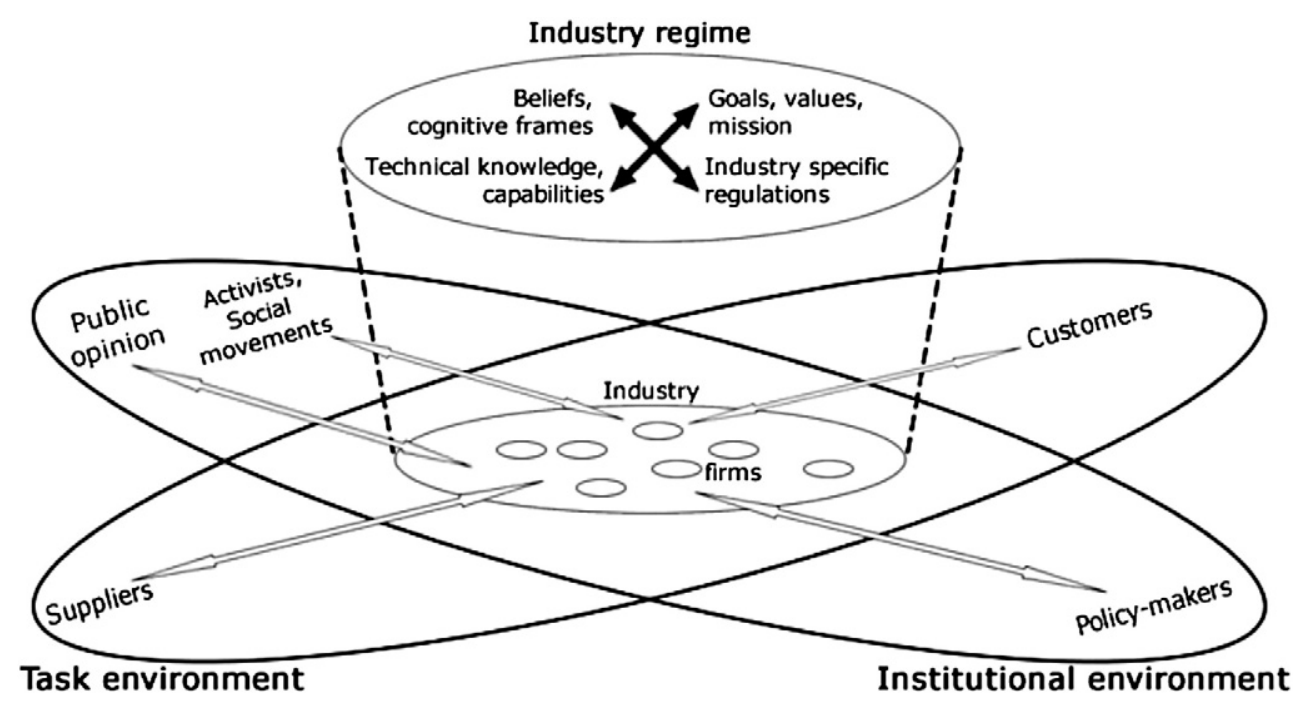

Fig. 1. Triple embeddedness framework of industries [18].

proposed four phases: a) emerging gap between societal expectations and firm performance; b) political debate and controversy; c) legislative phase; d) policy implementation.

While these early models proved useful, they were also criticised for too much focus on civil society and policy, and a relative neglect of industry strategies: "the perspective of the corporate strategist in dealing with the issues in the public policy arena can too easily be overlooked" [26] (p. 22). Secondly, interpretive disagreements about issues were downplayed [27]. Thirdly, the early literature placed too much emphasis on the 'focal' issue [26] and ignored the fact that industries simultaneously face multiple issues. Fourthly, the literature has been criticized for assuming a linear progression through stages.

To make issue lifecycle theory productive for the greening of industry research, we will address these criticisms. While Mahon and Waddock [26], Lamertz et al. [27] and Bigelow et al. [28] offer suggestions for addressing individual criticisms, we aim to develop a comprehensive model that address all four criticisms.

To address the first criticism, we pay more attention to the strategic responses from industry actors to 'green' pressures. Because of various lock-in mechanisms, industry actors are likely to resist major change, and use socio-cultural, political and (incremental) innovation strategies to defend the regime [16,29]. If 'green' pressures in institutional and task environments become stronger, industry actors may (reluctantly) introduce changes in regime elements. But only when 'green' technologies or 'green' markets offer economic opportunities, do industries become pro-active and implement comprehensive strategic changes $[5,15]$. Overall, we thus assume that the dynamic of 'green' issue lifecycles follows a dialectical logic, consisting of multidimensional struggles between evolving issue-related pressures in task and institutional environment and industry response strategies. To conceptualize this (internal) dynamic, we propose a five-phase Dialectic Issue LifeCycle model, which firstly addresses how 'green' issues gradually develop (through crossovers in the triple embeddedness framework) and gain momentum and secondly incorporates strategic responses from industry actors to issue-related pressures. Building on issue lifecycle theory, the DILC-model assumes that 'issues' emerge in civil society (via activists or social movements), then spill over to public opinion, and subsequently lead to political debates (if the issue is still supported by activists and public opinion). During the first three phases, industry actors use various defensive strategies to protect the existing regime. In the fourth phase, the issue spills over to the economic task environment (through regulations that affect economic frame conditions and changing consumer preferences) and industry actors gradually move to more substantive responses to address the issue (first diversification, then strategic reorientation), which leads to adjustments in the industry regime. The core mechanisms in the five phases are described below, while Fig. 2 schematically represents the overall logic in terms of the triple embeddedness framework. ${ }^{3}$ The model focuses on issue-dynamics and industry responses. ${ }^{4}$

\section{Phase 1: Problem definition and framing struggles}

Activist groups articulate the first concerns about an environmental problem. Because the problem is new, there is uncertainty about causes and consequences, which gives rise to framing struggles. Industry actors employ socio-cultural strategies that aim to ignore, deny or downplay the problem.

\footnotetext{
${ }^{3}$ Our distinction of five phases is based on a review of issue lifecycle models ([24-28]), complemented with insights from innovation studies [30,31].

${ }^{4}$ Our response to the third criticism (see below) acknowledges that industries also face other pressures in task and institutional environments.
} 

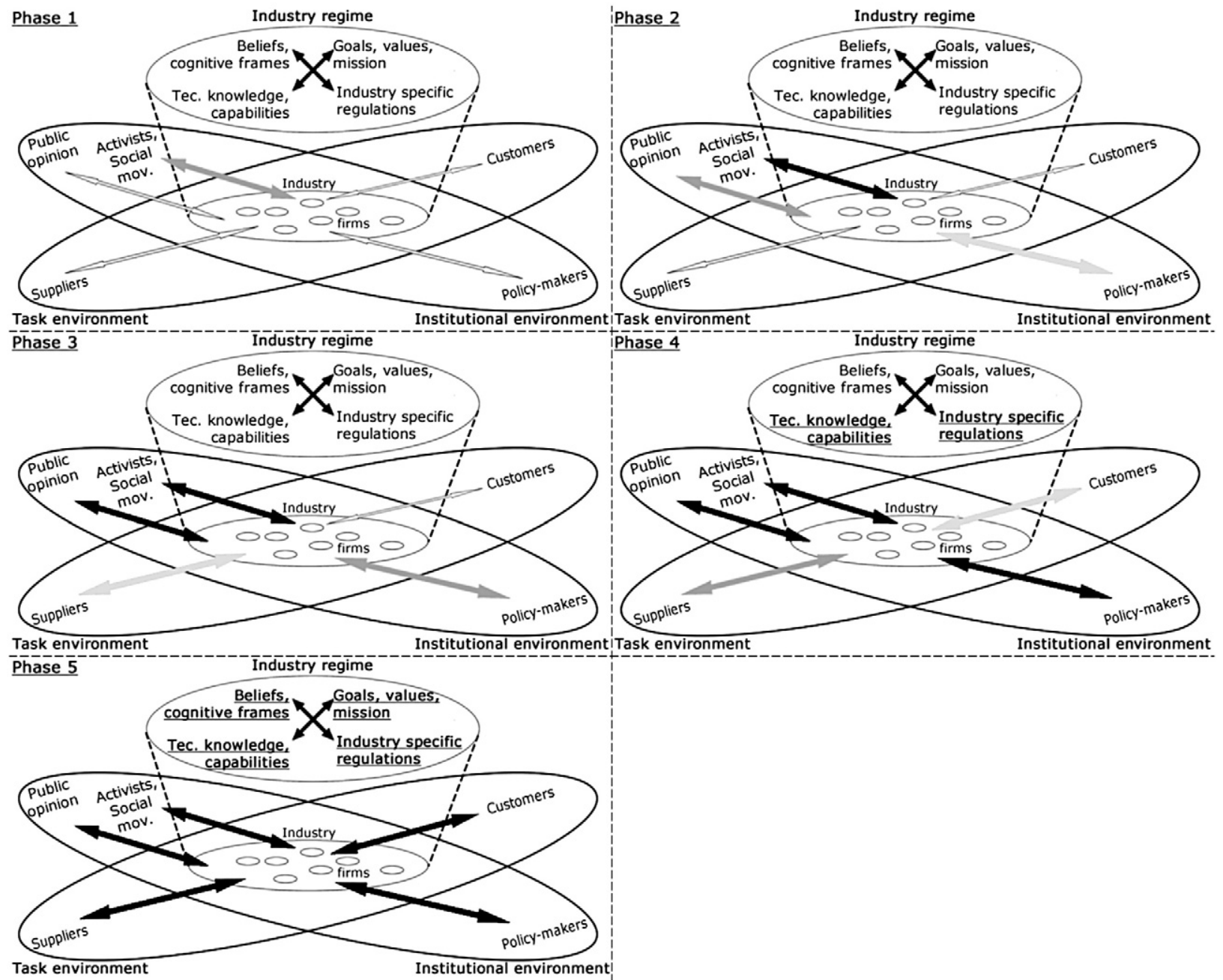

Fig. 2. Ideal-typical logic of five phases in the Dialectic Issue Life-Cycle (DILC) model.

Phase 2: Rising public concerns and defensive industry responses

Activists coalesce into a social movement that aims to push the issue onto public agendas [30]. Rising public concerns create credibility pressures on policy makers who may perform some symbolic actions (e.g. expressing concerns). Industry actors respond with framing strategies and political strategies. They may set up industry associations that contest the claims from social movements and lobby policy makers. If further denial of the problem damages the industry's reputation, firms may engage in incremental innovation that stays within the bounds of the existing regime.

\section{Phase 3: Political debates and defensive hedging}

If public opinion becomes more concerned, the issue may spill over to policy makers, who then engage in debates, hearings, and investigations. To influence the debates, industry actors use political and framing strategies, e.g. contesting the technical feasibility or emphasizing costs of possible solutions. They also tend to implement incremental innovations, arguing that regulations are not necessary, because they are already working on solutions. For defensive reasons they may also hedge and explore alternatives solutions based on new capabilities. The work by outside firms or suppliers on alternative solutions can undermine the argument from incumbent firms ('alternatives are not feasible'). Alternatives may also find a foothold in small market niches linked to 'moral customers' who are concerned about the issue.

Phase 4: Political regulations and diversification

If public concerns remain high, policy makers introduce tougher regulations and stimulate alternatives. But if concerns do not (yet) spill over to mainstream consumers, firms face conflicting pressures from institutional and task environments. They are therefore likely to diversify (rather than commit to comprehensive reorientation) and increase their R\&D investments in alternatives. Cracks may appear in the industry front, with industry associations defending the regime while individual firms break ranks 
and 'jockey for position’ (e.g. first mover advantages). Well-prepared firms may actually endorse environmental regulations to raise costs for competitors [31].

Phase 5: Spillovers to task environment and strategic reorientation

Sustainability issues can spill over to the economic task environment when public debates and discourses lead to changes in consumer preferences or when policy makers introduce tough policies (taxes, incentives, legislation) that change the economic frame conditions. Industry actors are then likely to change their economic positioning strategy. 'Green' innovations may become part of core beliefs, mission and business models.

To address the second criticism, we have incorporated framing struggles in the phase model [32], which implies that the meaning of the issue can change over time [27].

To address the third criticism, we use the triple embeddedness framework to emphasize that industries also face other issues besides 'green' pressures. Studies of the greening of industry should therefore not only analyze the internal dynamics of 'green' issue lifecycles, but also other pressures on industries, e.g. from markets, suppliers, new entrants, new technologies. In particular, we propose that positive or negative alignments with field-level pressures help explain accelerations or slowing down of issue lifecycle dynamics.

To address the fourth criticism, we characterize our phase-model as heuristic and ideal-typical, i.e. each stage accentuates distinct processes and mechanisms. While our phase-model assumes that 'green' pressures build up in one direction, we recognize that alternative paths are possible if pressures decrease or if industries successfully fight back [28]. Empirical cases should thus be contrasted and analyzed against the ideal type phase model. We will come back to the issue of alternative paths in the analysis section.

\section{Methodology and data sources}

To illustrate our model, we confront it with a historical case study. Case studies are the most-suited approach for studying complex qualitative changes over time that entail enactment and changing contexts as in our model [33]. We chose a historical case, local air pollution and the American car industry (1943-1985), because this enables a longitudinal study of issue lifecycles and industry change. Smog first emerged as an issue in civil society and gradually spilled over to regulatory, economic and technical dimensions. The case also contains protracted resistance from the industry, both through collective and firm-level strategies, followed by reorientation and implementation of catalytic converters. Although catalytic converters are sometimes characterized as incremental end-ofpipe solutions, they required the industry to acquire new technical competencies in chemistry (for oxidation catalysts in the early 1970s) and electronics (for three-way catalysts in the late 1970s). Three-way catalysts also entailed architectural reconfiguration of engine design, so was less incremental than often assumed.

The case study draws on primary and secondary sources. Primary sources for public protests and discursive framings are articles from the Wall Street Journal and newspaper cartoons. We collected primary quantitative data from governmental sources (e.g. the Environmental Protection Agency; Department of Transport) and industry journals (e.g. Ward; Automotive news). We also selected the case because of the availability of various secondary sources. From an engineering perspective, Mondt [34] and Lester [35] highlight the technical choices and concerns in emission control development. From an innovation studies perspective, Lee et al. [36] analyse patents and learning curves, while Nil and Tiessen [37] studied the competition between catalyst and lean burn technologies. From a policy studies viewpoint, Krier and Ursin [38] made a detailed description of the federal and state level policy processes, while Luger [39] and Doyle [40] made a broader political economy analysis of the struggles between policy makers and the car industry. For the broader industry and context analysis we draw on various secondary sources [41-47].

The case study's primary aim is not to uncover new empirical data, but to illustrate and test our conceptual model. Nevertheless, our analysis deviates in several respects from previous studies. First, many studies start with the 1970 Clean Air Act [36,37,48]. Instead, our study starts in 1943, which enables analysis of framing struggles over the definition of air pollution and the mobilization of protests. Second, we make a comprehensive multi-dimensional analysis, while most previous studies have a more focused disciplinary angle. Thirdly, whereas many studies see catalyst innovation as forced by policy, we also include the role of competitive dynamics, especially the role of General Motors (GM) as product champion. So, while we build on previous studies, we also aim to make a more comprehensive analysis.

\section{Air pollution and the American car industry (1943-1985)}

To investigate how the case study matches with the core mechanisms in the DILC-model, we analyse the evolution of the issue of air pollution (smog) and the responses from the car industry. We have deliberately divided the case study into five periods (1943-1953; 1953-1960; 1960-1970; 1970-1977; 1977-1985) to interrogate the mechanisms in our five-phase model and the overall pattern. In line with the DILC-model and our emphasis on broader concerns that are not related to the focal green issue, we will discuss each period in terms of two analytical considerations: 1) the issue lifecycle, which describes the dialectic interaction between: a) various pressures around the air pollution issue, b) car industry responses; 2) the broader industry evolution, which describes: a) other pressures in task and institutional environments, b) general corporate strategies and how these draw on regime dimensions. Incorporation of the second analytical section makes our case study different from existing empirical studies. While existing studies focus primarily on air pollution, our case study also recognizes that the car industry faced pressure 


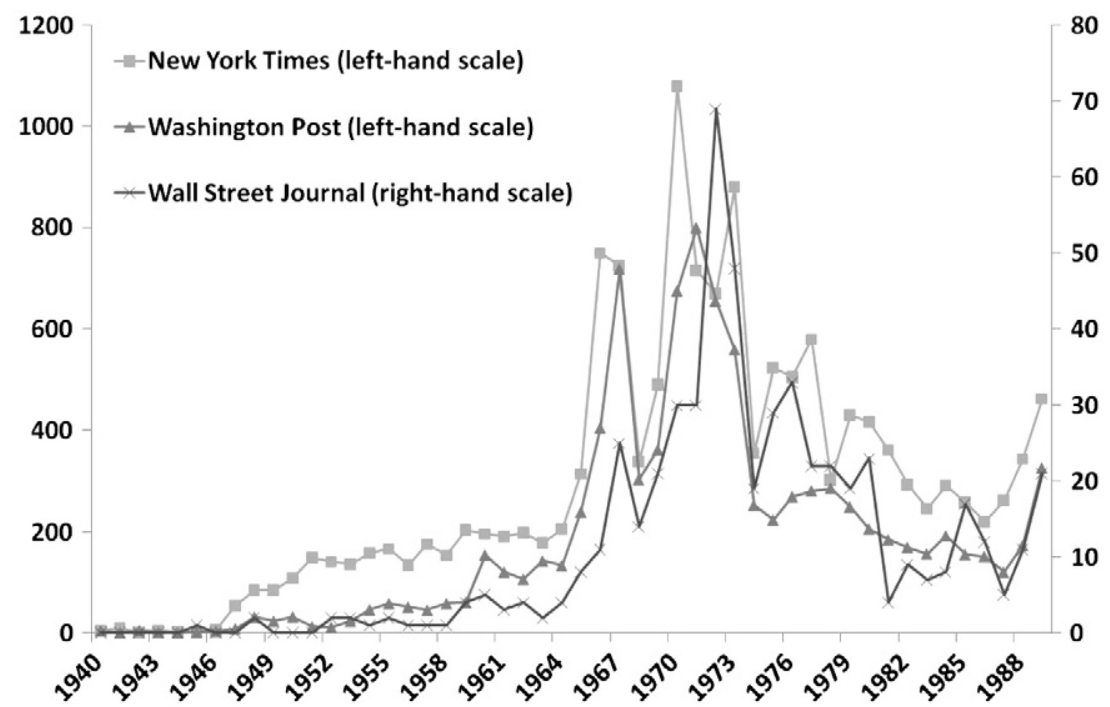

Fig. 3. Yearly number of articles in national newspapers about air pollution ${ }^{5}$.

5 The graph is based on data from a keyword search in the digital archives of these newspapers. We used 'air pollution' and 'smog' as keywords. Duplicated articles were excluded.

from issues such as safety, fuel efficiency, competition from foreign new entrants, market fluctuations and financial problems, which positively or negatively interacted with progress of the air pollution issue. ${ }^{6}$

Public attention to air pollution, which was one of the important drivers for issue evolution, accelerated in the 1960s, peaked in the early 1970s, and then gradually diminished as other issues (oil shocks, fuel efficiency, economic problems) came to the fore. We quantitatively plotted this pattern in Fig. 3, although we recognize that newspaper counts are only a rough indicator of public attention. Still, this pattern confirms the plausibility of our periodization, especially for the later phases. We chose 1985 as cut-off point, because policy makers and the public perceived the installation of the three-way catalytic converters as a satisfactory solution. Concerns in the late 1980s over acid rain, the ozone layer, and climate change represented new issue attention cycles, which fall outside our scope.

\subsection{Issue emergence and sensemaking attempts (1943-1953)}

\subsubsection{Issue lifecycle}

\subsubsection{Pressures around issue}

Social movements and public opinion. The issue emerged in California, where episodes of severe smog (in 1943, 1946, 1949) caused eye irritation, coughing, and respiratory discomfort, which led to public complaints and petitions to elected officials [49]. Initial sensemaking attempts saw manufacturing and industrial districts as the principal offenders. But in the late 1940s, scientific research into photochemical reactions (by Haagen-Smit) pointed to refineries and automobiles as causal factors $[38,40]$.

Policy-makers. Although local policy makers expressed some concerns about smog, they did not go beyond "well-publicised but essentially token enforcement efforts" [49] (p. 134). Officials promoted research via the newly created (1947) LA County Air Pollution Control District (APCD), which hired Haagen-Smit.

4.1.1.2. Car industry issue responses. The car industry denied that cars caused smog problems [49]. Industry actors undertook neither political nor innovation strategies, because the issue was seen as insignificant. The oil industry, which was also implicated in early criticisms, sponsored research to contest Haagen-Smit's findings [38].

\subsubsection{Broader industry evolution}

\subsubsection{Broader industry contexts}

Institutional environment. The car industry enjoyed high political legitimacy, because of its weapon manufacturing effort during the war, and because of post-war economic and employment contributions [39]. Culturally, the car became an American icon, representing modernity and progress. Large cars expressed personal success [42].

\footnotetext{
${ }^{6}$ Issues that receive less attention are labour relations, international markets, dealerships, internal company struggles, and consumer finance facilities provided by car companies.
} 
Task environment. In the post-war decade, passenger car sales grew about 3.7\% per annum, with the Big Three selling about $86 \%$ of all cars. The oligopoly enjoyed high profitability [42].

4.1.2.2. Industry strategies and regime dimensions. The industry's economic (positioning) strategy was oriented towards the more profitable large-car market [42]. The small-car market was left to other manufacturers and imports. Marketing strategies were organized around annual model changes and the notion of 'consumption ladder' (moving upwards to bigger cars).

As finance and accounting men became corporate leaders, the industry's mission came to focus more on share prices, profits and costs $[43,50]$. The finance men had little interest in the automobile as a mechanical device, and perceived innovation as expensive, risky, and unnecessary [47]. Instead, the emphasis was on non-functional styling and gadgetry such as tail fins and chrome [42].

Despite some exceptions such as the V8 engine, hemispherical combustion chambers, automatic transmission, and hydraulic shock absorbers [46], there was little product innovation. "With the addition of automatic transmissions in the 1940s, the dominant design was completed that was to hold the American market in its grip for the next thirty years. (...) changes in this allpurpose roadcruiser were largely a matter of incremental refinement" [41] (p.115). Other companies followed GM's conservative product strategies, because GM "had the money to spend competitors into the ground" [45] (p. 97).

\subsection{Policy learning and defensive industry responses (1953-1960)}

\subsubsection{Issue lifecycle}

\subsubsection{Pressures around issue}

Social movements and public opinion. The 1953 'five-day siege of smog' (in Los Angeles) heightened public concerns [38]. Public pressure further increased with the formation of anti-pollution groups such as Stamp Out Smog (SOS) in 1958 [49]. Ongoing medical research helped change the framing of smog from 'nuisance' to 'health risk' [51].

Policy-makers. The 1953 shock and rising public concerns led to policy debates, investigations and policy learning. Californian policy makers began discussing the creation of regional pollution control districts, while California's Governor sponsored research, which confirmed that automobiles were important contributors to smog problems. The Federal Air Pollution Control Act (1955) also stimulated studies on the causes and (health) effects of air pollution. A study by the Surgeon General was debated at the First National Conference on Air Pollution in 1958, and prepared the ground for the 1960 Schenck Act that made the study of motor vehicle emissions part of the remit of the Surgeon General [40]. In 1959, air quality was made part of the mission of the California Department of Public Health, something that strengthened the issue's health framing [38].

\subsubsection{Car industry issue responses}

Socio-cultural and political strategies. The car industry argued that the understanding of air pollution was too uncertain to assign blame [38]. GM further claimed that Los Angeles was a special case because of topographical and meteorological conditions [40].

The car industry also participated in the Air Pollution Foundation (APF), which further included other firms (e.g. Union Oil Company, Firestone Tire \& Rubber Company, U.S. Steel). APF-sponsored research confirmed that automobiles strongly contributed to smog [49]. Although the car industry acknowledged the findings, it pointed to uncertainties and insisted on further investigations [40]. The car industry further aimed to 'divide and rule' between state and federal levels, arguing that national regulations were not necessary because California was a special case.

Technology innovation strategy. The car industry also adopted innovation strategies, which were coordinated by the newly formed (1953) Vehicle Combustion Products Committee of the Automobile Manufacturers Association (AMA) [40]. While this Committee publicly claimed to develop emission control technologies, it contained a secret agreement that competitive struggles through innovation should be avoided [39]. To create a closed industry front, the Committee rather than individual companies would manage public communications. The research program focused on incremental innovations in engine components, such as the Positive Crankcase Ventilation (PCV) valve. Although PCV devices cost only $\$ 10.00$ per car, ${ }^{7}$ car manufacturers complained about the extra costs of installing pollution control devices [40]. The industry also argued that regulations were not needed, because solutions were in the making.

There was also some work on more radical alternatives. AMA's Exhaust System Task Group, formed in 1955, investigated oxidation catalysts [35]. In 1957 Ford announced that it was working on vanadium pentoxide catalysts, while Chrysler announced the development of better tuned engines. GM reprehended both initiatives through the AMA, reminding both companies of their agreement on managed publicity and threatening them with sanctions [40].

\footnotetext{
${ }^{7}$ In 1962 dollars ( $=\$ 75$ in 2011 dollars). A best-selling sedan, such as the 1962 Chevrolet 409, cost about $\$ 2500$ in 1962 dollars (= $\$ 18,600.00$ in 2011 dollars).
} 


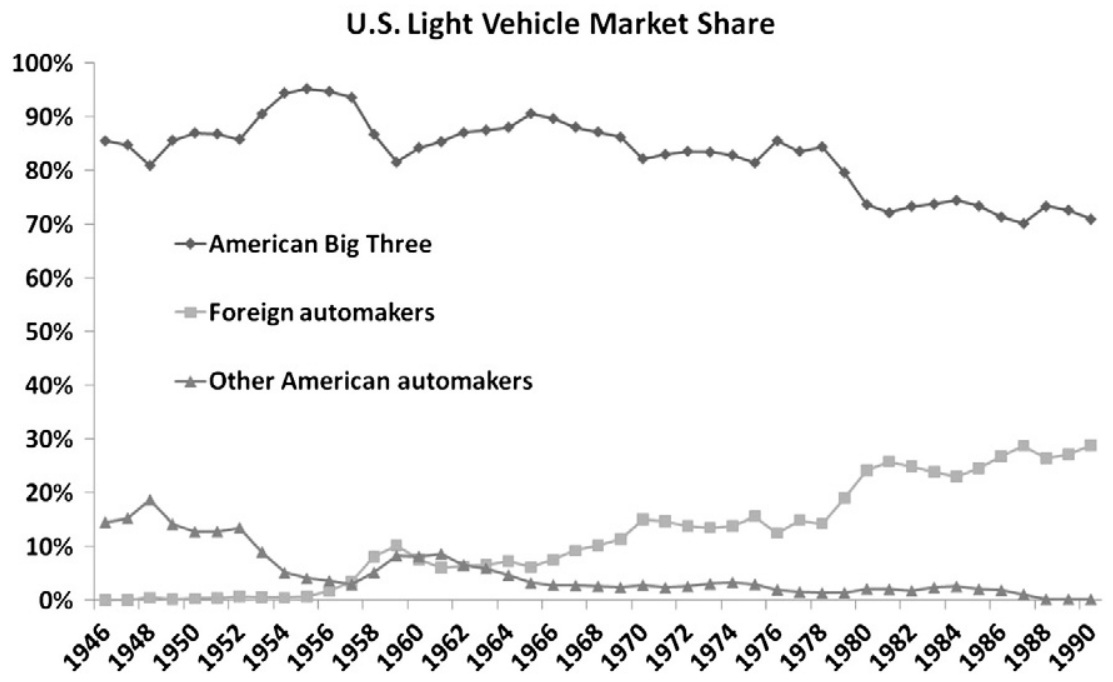

Fig. 4. U.S. light vehicle market share, 1946-1990 (Data source: Until 1961, [46]; after, Ward's Automotive Group).

\subsubsection{Broader industry evolution}

\subsubsection{Broader industry contexts}

Institutional environment. The industry's political legitimacy was still high, as indicated by the passage of the Interstate Highway Act (1956). The government did not interfere with technical design or business practices, granting the car industry much autonomy [39]. This prevailing sentiment was captured by a 1953 statement of the Secretary of Defence, and former GM president Charles Wilson, that 'what is good for the country is good for General Motors and vice-versa'. Cultural legitimacy was also high, as vehicle ownership increased more than 4\% per annum in the 1950s, reaching more than 60 million registrations by 1960.

Task environment. Car sales generally increased throughout this period. The first post-war recession caused a temporary sales decline from 7.2 million in 1957 to 5.1 million in 1958 [42], and a growth in the small-car market segment, of which foreign car manufacturers (Volkswagen, Renault) took advantage. Market shares of foreign new entrants increased from $0.71 \%$ in 1955 , to $10.17 \%$ in 1959 (Fig. 4).

4.2.2.2. Industry strategies and regime dimensions. The industry's positioning strategy remained directed towards the large car segment, where firms competed on styling, gadgets, and costs. The small-car market formed an entry point for foreign manufacturers [40,47]. Innovation strategy remained of limited priority. "The American automobile industry [lagged] far behind foreign competition in the 1950-1980 period in developing and adopting state-of-the-art innovations that improved fuel economy, performance, handling, and safety" [42] (p. 292). In the late 1950s, the Big Three responded to the foreign imports by building their own compacts models, e.g. Ford Falcon; Dodge Dart; Plymouth Valiant [42]. This entailed an innovation effort and the development of new engine concepts (e.g. rear-mounted, air-cooled aluminium engines), and changes in transmissions and chassis design. Although the transilience index ${ }^{8}$ of innovation briefly improved (Fig. 5), these innovations were targeted towards a special market niche, and limitedly affected mainstream (large car) technologies. The compact models achieved disappointing sales, which hardened Detroit's negative beliefs about the small car market [47].

\subsection{Increasing public concern, early legislation and industry delay (1960-1970)}

\subsubsection{Issue lifecycle}

\subsubsection{Pressures around issue}

Social movements and public opinion. Smog problems appeared in other states (New York, Philadelphia) as car ownership increased [40]. The scientific understandings of health effects also grew [51], which brought physicians into the debate. The framing of smog as dangerous killer (Fig. 6) added a sense of urgency. This public framing resonated with new cultural sensitivities about environmental vulnerability [52]. New activist groups, e.g. Clean Air Council (1967) and Group Against Smog and Pollution (1969), coalesced with physicians and environmental groups into a social movement, which organized protests and disseminated information about air pollution [51]. Air pollution concerns increasingly spilled over to public opinion.

\footnotetext{
${ }^{8}$ The transilience index reflects the degree of technical difficulty of innovations over time. For the 1894-1980 period, Abernathy et al. [41] construct this index for the American car industry, based on a coding of 631 technical innovations using a 7-point scale (based on how disruptive the innovation is to the production process).
} 


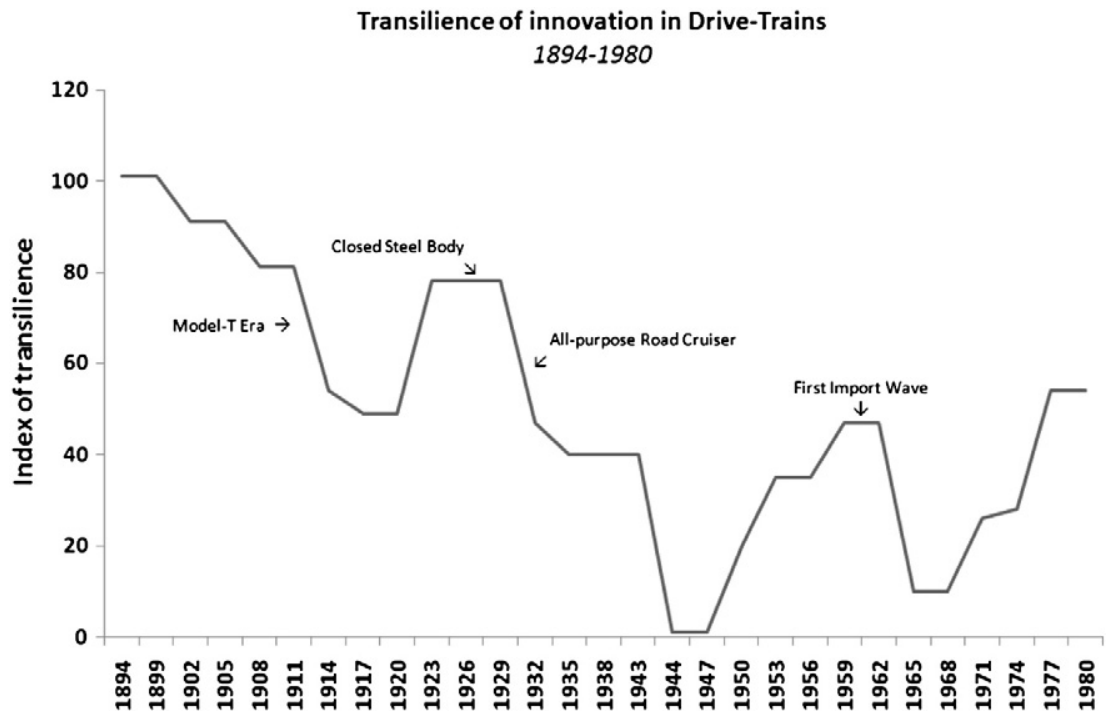

Fig. 5. Pattern of innovative activity of the American automobile industry ([41], p. 115).

In 1969, public opinion was also influenced by an anti-trust case against the Big Three and the AMA, which informed the public about the conspiracy to delay pollution control innovation [40]. Public outrage damaged the industry's legitimacy and seemed to validate the belief that "the auto industry would heed the public interest only if it were forced to by Congress" [39] (p. 86).

Policy-makers. Air pollution entered the legislative phase when California adopted the Motor Vehicle Pollution Control Act (1960), which specified the first emission standards for car exhausts [49]. In 1961, the California's Motor Vehicle Pollution Control Board was created to certify new emission control technologies [34]. The 1963 Clean Air Act (CAA) signalled stronger federal involvement, followed by a rapid increase in the number of bills introduced in the House and Senate (Fig. 7). The Federal Motor Vehicle Pollution Control Act (1965) announced the first national emission standards for cars, which followed what the industry said was feasible [38]. But as policy makers got frustrated with the industry's delay tactics and slow technical progress, debates gradually moved towards more willingness to tighten regulations.

\subsubsection{Car industry issue responses}

Socio-cultural and political strategies. The car industry aimed to slow legislative progress. In the early 1960s, automakers 'voluntarily' installed PCV devices, arguing that regulation was not needed [40]. Recurring framing strategies were that California was

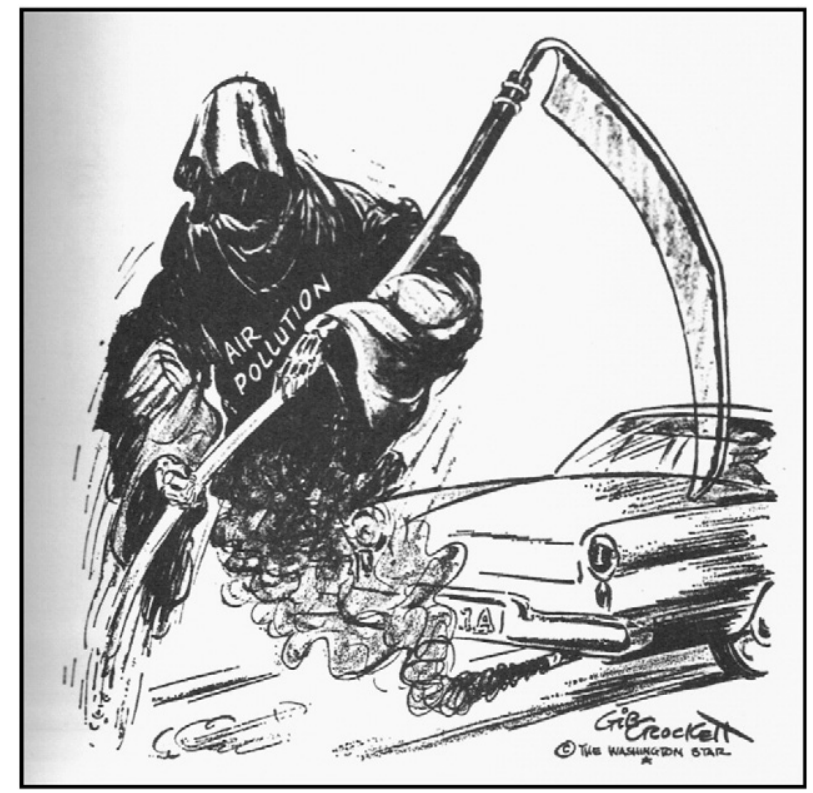

Fig. 6. Health risk framing of air pollution in the early 1960s (cartoon from Washington Star newspaper reprinted in [53], p. 3). 


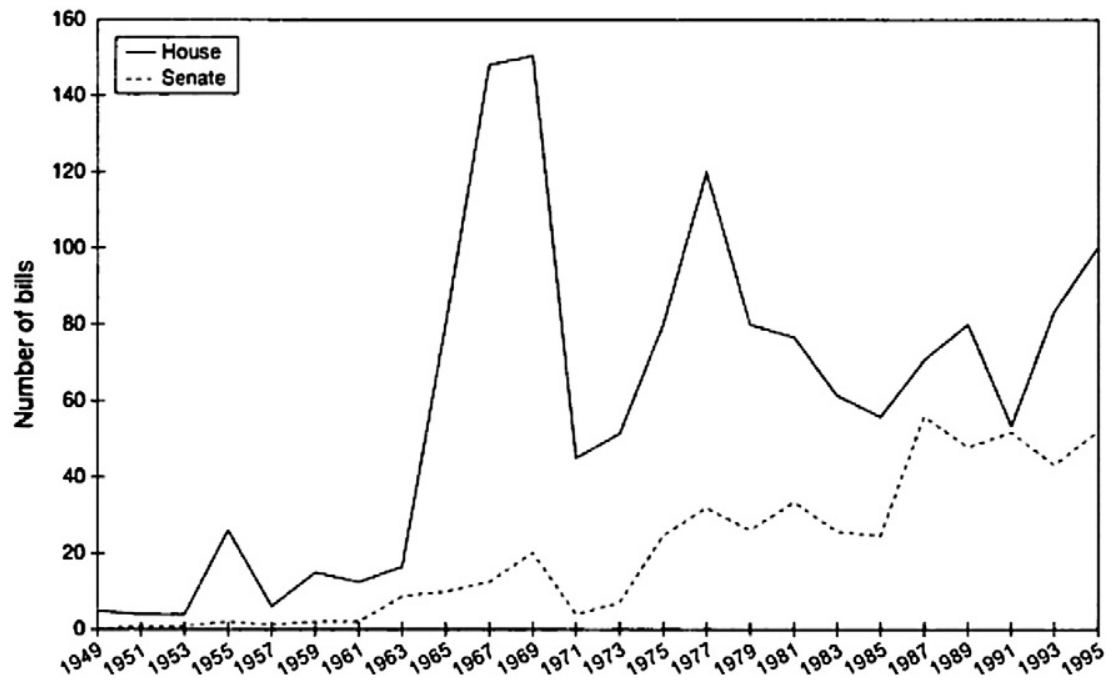

Fig. 7. Number of air pollution control bills introduced [54].

a special case [39] and that the costs of pollution control technologies were substantial, an argument that newspaper cartoons mocked (Fig. 8). But when other states (New York, Philadelphia) began introducing pollution control laws, the industry changed its position and began arguing for federal standards: "When faced with the threat of inconsistent and increasingly rigorous state laws, they... [used] their superior organizational capacities in Washington to preempt or control the environmentalists' legislative victories at the state level" [55] (p. 326).

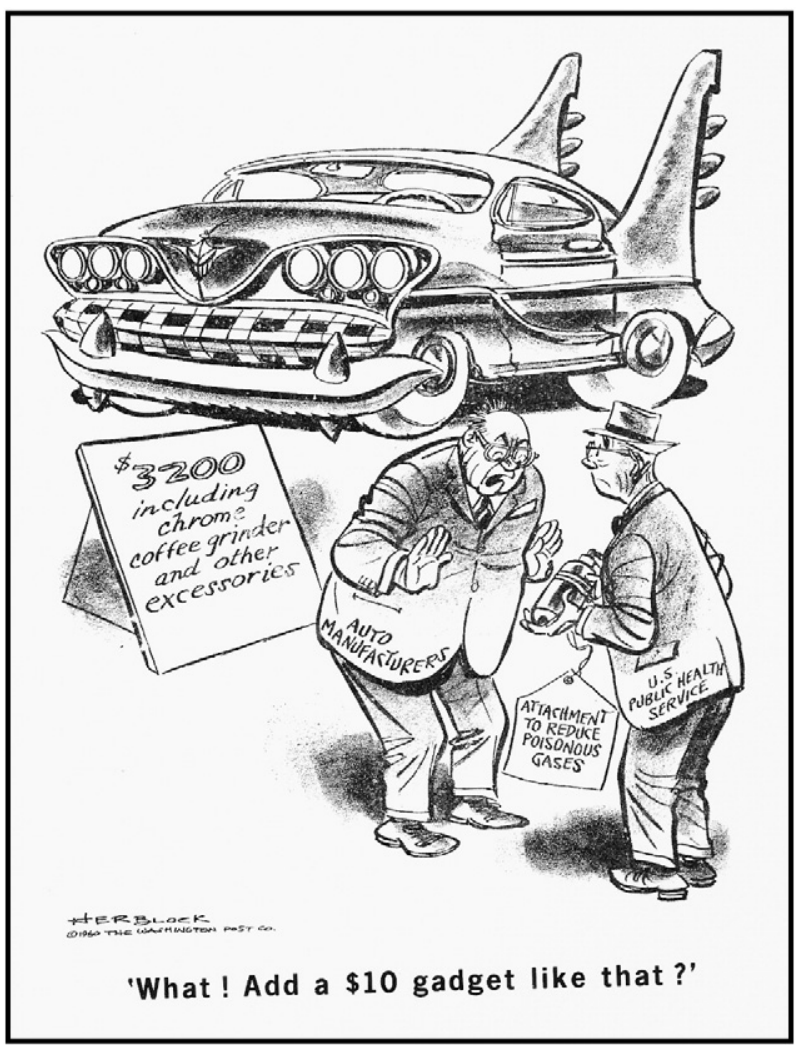

Fig. 8. Automakers' reaction to 'attachments to reduce poisonous gases' offered by the U.S. Public Health Service (Source: published by the Washington Post in 1960 , reprinted in [53], p. 53). 
Technological innovation strategy. The industry focused on incremental improvements in combustion engine components, e.g. PCV valves; evaporation-control systems (ECS); transmission controlled spark (TCS); thermovacuum switches (TVS), air injected reactors (AIR) [34]. Automakers resisted the implementation of catalytic devices developed by suppliers. But they did set up R\&D programs to investigate the technology [34,35]. Ford joined the Inter-Industry Emission Control Program (IIEC1, 1967-1973), while GM created its own catalyst R\&D program [34]. In 1968, GM found that unleaded fuel diminished catalyst degradation, which has been a serious problem [35].

New entrants and outsiders. Outsiders such as American Cyanamid, Walker Manufacturing, and Universal Oil developed catalyst technologies [35]. In 1962, Engelhard Industries successfully tested catalytic converters in automobiles [40]. But the car industry, characterized by strong vertical integration, did not buy these new technologies, because they did not want to sell and warrant vehicles equipped with expensive devices made by third parties [34].

\subsubsection{Broader industry evolution}

\subsubsection{Broader industry contexts}

Institutional environment. The industry's reputation was further eroded by Nader's book Unsafe at Any Speed (1965), which criticized its reluctance to introduce safety features like seatbelts [39], and by the subsequent Ribicoff hearings (1965-6) which exposed secret recall campaigns through which one in five cars had been recalled for safety defects between 1960 and 1966 . "Since this revelation came on the heels of the industry's refusal to support any form of federal regulation, legislators now were inclined to see the industry as not just uncooperative but as unreasonable" [39] (p. 72). The safety issue resonated with the air pollution issue and strengthened the political willingness to introduce stricter legislations.

The rise of an 'activist culture' and new environmental groups (Environmental Defense Fund (1967); Friends of the Earth (1968); Environmental Action (1970); Greenpeace (1971)) further strengthened the public discourse about air pollution.

Task environment. Annual car sales rose from 6.1 million in 1959 to 8.4 million in 1970 (Fig. 9), boosting the industry's returnon-investment [50]. In the late 1960s, the Big Three's market share began to decrease (Fig. 4), because of increasing foreign imports, especially from Germany and Japan. Japanese manufacturers made cheaper cars, and also continued to upgrade their performance in reliability, quality and handling [44].

\subsubsection{Industry strategies and regime dimensions}

Positioning strategy. American manufacturers remained oriented towards big cars, styling, gadgetry, finance, and stocks $[43,47]$. Technological innovation was limited in the 1960s [41] and the transilience index of innovation decreased (Fig. 5). The quality of cars also received limited attention, because the manufacturing process was optimized on speed and cost rather than on precision, accuracy and failure rates [47].

American automakers paid little attention to Japanese new entrants in the small-car market. They joked that you had to close the doors of Japanese cars gently in order not to bend them (reported in [43], p. 311). Other shared belief systems were that air pollution was trivial and that 'safety does not sell' [44]. In the late 1960s, however, automakers felt increasingly under siege

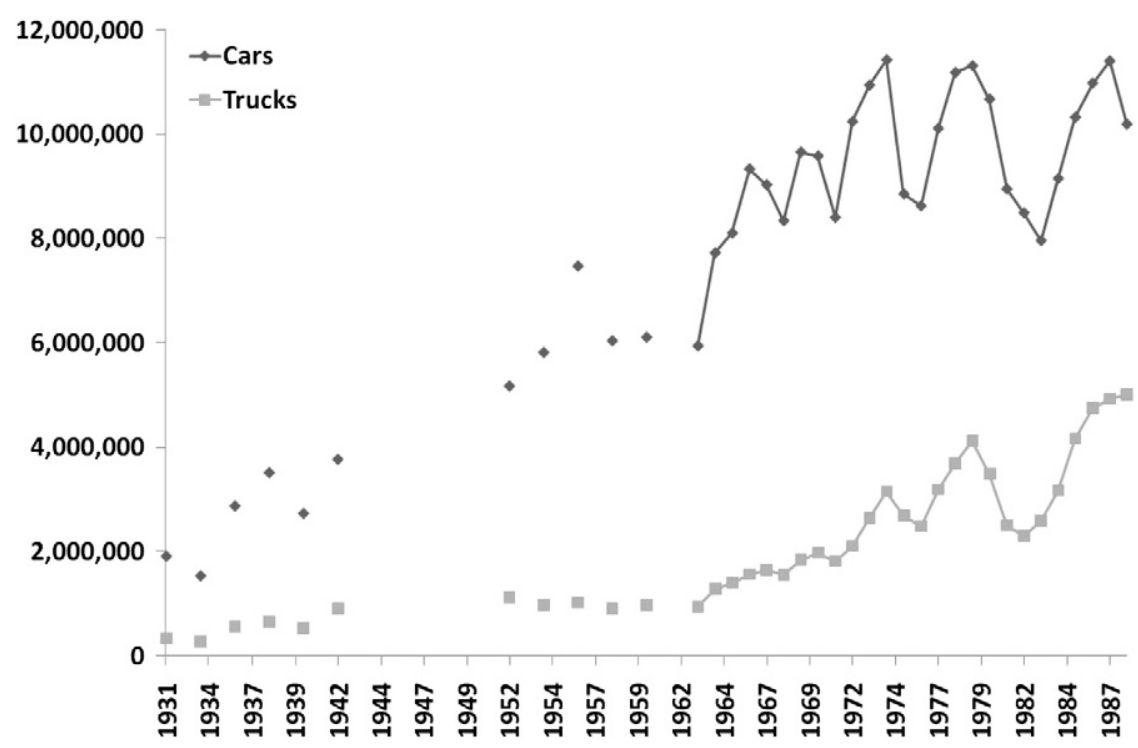

Fig. 9. Annual car sales in the American market (Data source: Ward's Automotive Group ${ }^{9}$ ).

\footnotetext{
9 Data from Ward's are available at www.wardsauto.com/keydata/ (downloaded on 29/7/2010).
} 
and experienced tightening regulations on air pollution and safety as constraints on their freedom [43]. Industry resistance against safety and air pollution became part of an ideological struggle over managerial autonomy: "the industry's reaction was part of a larger battle to minimize government authority over the future direction of auto design" [39] (p. 81).

\subsection{Tough legislation and resisted implementation (1970-1977)}

\subsubsection{Issue lifecycle}

\subsubsection{Pressures around issue}

Social movements and public opinion. Public pressure peaked during the 1970 Earth Day event (Fig. 3). The United Auto Workers (UAW) joined the 'Coalition for Clean Air', which lobbied the Senate for stricter auto emissions regulations [39].

Policy-makers. Congress enacted the 1970 Clean Air Act (CAA) Amendments, which was a tough regulation that demanded 90\% reductions in $\mathrm{HC}$ and CO emissions by 1975 and in $\mathrm{NO}_{\mathrm{x}}$ by 1976 [34]. The CAA specified a $\$ 10,000 /$ vehicle fine for firms selling cars that did not comply [39]. ${ }^{10}$ The CAA was the culmination of reinforcing processes: a) decreasing legitimacy of automakers; b) increasing political frustration over the industry's delay tactics; c) macro-cultural trends such as rising environmentalism and social activism; d) political jockeying between Senator Muskie and President Nixon [55]. ${ }^{11}$

CAA implementation was delegated to the newly created Environmental Protection Agency (EPA), which could also regulate fuels [56]. Lead as a fuel additive was a matter of concern, because of its effects on human health and the durability of catalytic converters [35]. Since 1971 EPA therefore issued regulations that progressively removed lead from gasoline and ordered the sale of unleaded gasoline in 1975 [56].

The CAA pushed automakers towards more comprehensive innovations [39]. But the CAA also contained a loophole, because standards could be postponed if this was in the public interest and if the requisite technology was not available. The industry exploited this loophole by petitioning and then suing for extensions, arguing in court that technology to meet emission standards was not yet available $[40,48]$. In 1973, when the court favoured a delay, EPA postponed the HC and CO emission standards to 1976, and $\mathrm{NO}_{\mathrm{x}}$ standards to 1977 [48].

The 1973 energy crisis influenced the air pollution struggle, because it changed the public focus to economic problems and fuel efficiency. When the car industry claimed that pollution control hindered fuel economy, Congress extended standards to 1977 ( $\mathrm{HC}$ and $\mathrm{CO})$ and $1978\left(\mathrm{NO}_{\mathrm{x}}\right)$. In 1975, EPA further extended $\mathrm{HC}$ and CO standards to 1978 [35].

\subsubsection{Car industry issue responses}

Socio-cultural and political strategy. Top managers became involved to influence the political process. They created a task force to lobby senators to reject the law [40]. When the CAA was accepted, strategies shifted towards hindering implementation (through petitions, hearings, litigation). They argued that the technology was not available and that high costs would cause a business catastrophe [40]. Estimates suggested that catalytic converters, thermal reactors, and exhaust gas recirculation would cost $\$ 860$ per vehicle [34], increasing the price of best-selling cars by 30\%. Following the 1973 oil crisis, Detroit emphasized tradeoffs between pollution control and fuel efficiency [39].

Foreign new entrants undermined the industry's claims about technical unfeasibility. In 1972, Honda reported that its Compound Vortex Controlled Combustion (CVCC) engines already met CAA standards. Mazda and Mercedes-Benz made similar claims for their rotary and diesel engines [40]. Catalyst suppliers challenged the industry's claim that catalytic converters presented too many problems [40].

Innovation strategy. American automakers stepped up their innovation efforts, which resulted in more patents on emission control technologies (Fig. 10).

Initially they focused on further incremental engine modifications, adding air pumps, spark retardation, thermal afterburners, and exhaust gas recirculation to existing engines. Because these modifications had negative effects on fuel economy, performance and driveability [34,35], the industry gradually moved towards catalytic converters [37]. Because catalyst suppliers had a technological lead, GM and Ford stepped up their R\&D efforts, leading to increased patenting activity (Fig. 10). GM gradually turned into a product champion for catalysts and in 1973 announced that it would install catalytic converters in 1975MY cars. With this surprise move [45] GM attempted to gain competitive advantage in the subsequent innovation race, e.g. using patents to create barriers for competitors, licensing catalytic converters to Nissan and American Motors [61,62], exploiting its investments in South African platinum futures [57] (p. 371).

The introduction of catalyst technology in 1975 increased car prices by $\$ 580.73$ per vehicle (in 2011 dollars, see Fig. 11). Retooling of production lines raised capital expenditures from \$242 million in 1974 to \$1.57 billion in 1975 [48].

\footnotetext{
1010,000 (1970) dollars amounts to 58,000 dollars in 2011.

11 Muskie, a possible candidate for the 1972 presidential elections, introduced proposals for stricter emissions in 1969 . Nixon upped the ante and proposed even tougher standards (90\% reductions) for 1980. Muskie then adopted similar standards but tightened the deadline to 1975 [48].
} 


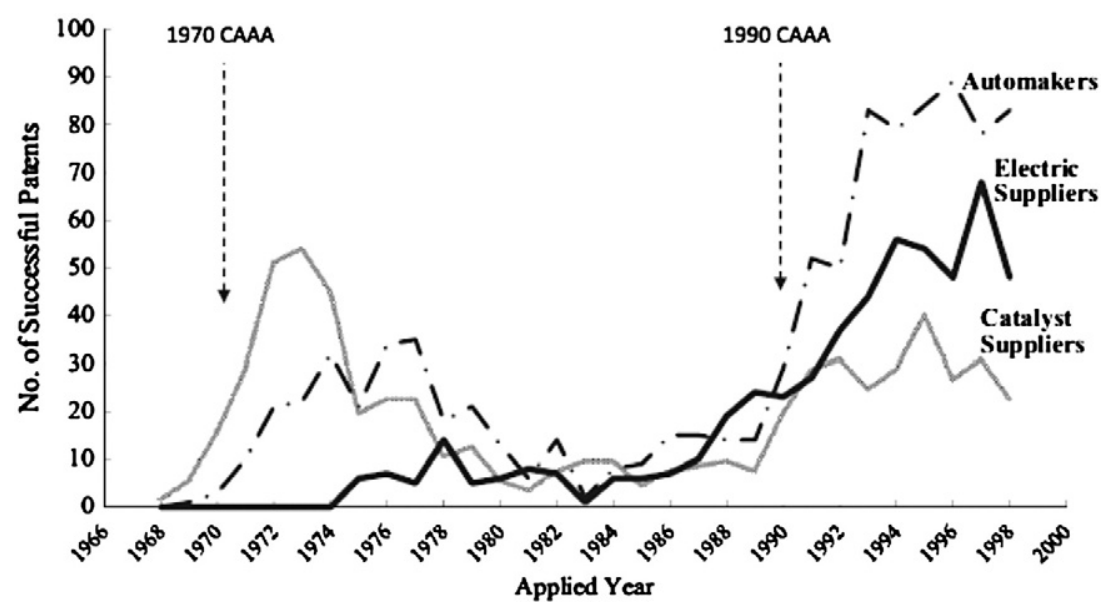

Fig. 10. Emission control patents for automakers, catalyst suppliers and auto electronics [36] (p. 257).

\subsubsection{Broader industry evolution}

\subsubsection{Broader industry contexts}

Institutional environment. Public concerns about car quality increased, as automakers issued hundreds of recall campaigns, involving millions of vehicles with defects (Luger, 2000). These campaigns, which had become media events, damaged the reputation of American automakers [47].

The 1973 energy crisis not only diminished media attention for environmental problems [52] and air pollution (Fig. 3), but also contributed to an economic recession from late 1973 to early 1975, and a 3.1\% fall in GDP.

Task environment. American car sales shrank in 1970 (-11.6\%), 1974 (-20.80\%) and $1975(-3.80 \%)$, causing economic setbacks for GM and Ford, and financial losses for Chrysler (Fig. 12). Rising oil prices stimulated demand for small, fuel-efficient cars, which benefitted Japanese imports. But "after trying the cars for gas mileage, Americans found they liked their reliability" [44] (p. 10). Japanese cars increasingly acquired an image of "quality, workmanship, engineering creativity, and durability, as well as low operating costs" [47] (p. 140).

4.4.2.2. Industry strategies and regime dimensions. The industry did not incorporate environmentalism in its mission, but instead adopted "a 'culture of resistance' on environmental matters" [40] (p. 15). The shared belief was that environmentalism was externally imposed, not demanded by customers. But the external pressures also brought innovation back on the agenda of corporate

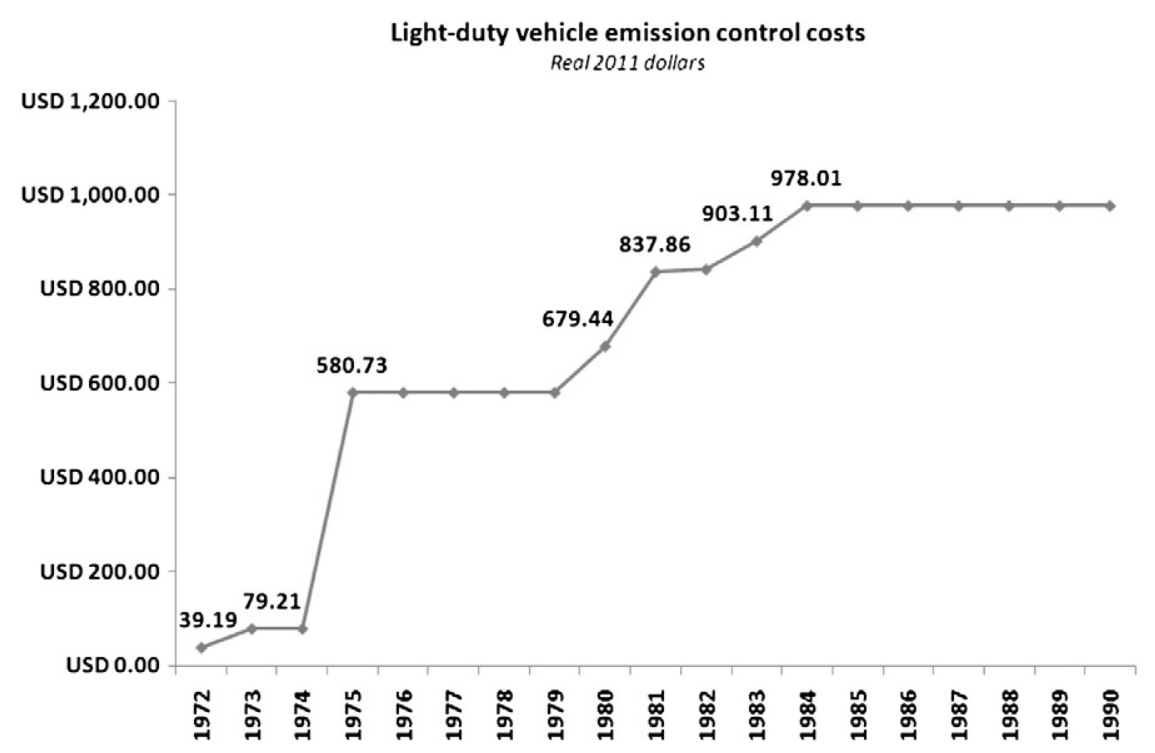

Fig. 11. Emission control technology cost per vehicle (sum of costs for all control technologies such as catalytic converters, EGR units etc.) [58] (p. C-19). 


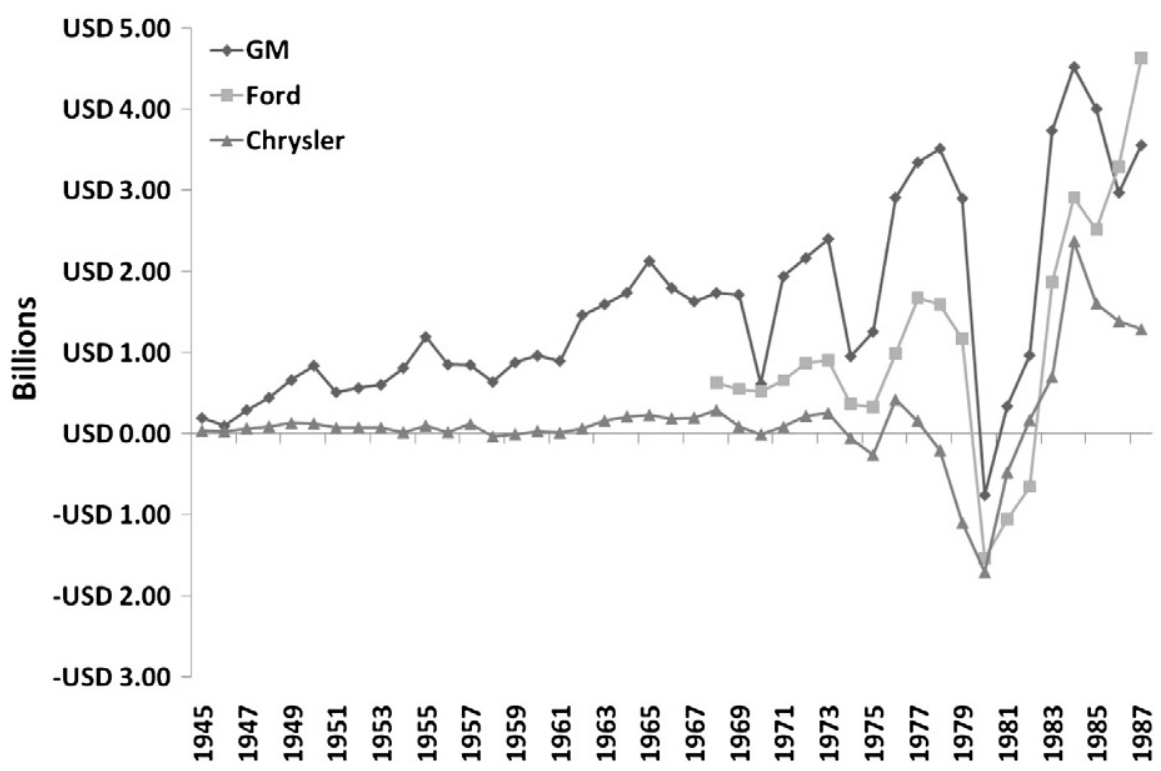

Fig. 12. Net income of the Big Three car companies, current dollars (sources: [50] for GM; [59] for Chrysler; [60] for Ford 1969-1986).

strategists: "The energy shocks of the 1970s, coupled with the government mandates for clean air, ended Detroit's technological stagnation" [47] (p. 202).

\subsection{Industry fightback, implementation delays, and institutionalization (1977-1985)}

\subsubsection{Issue lifecycle}

\subsubsection{Pressures around issue}

Social movements and public opinion. Public attention for air pollution diminished (Fig. 3), while attention for the car industry's economic problems increased. The Big Three posted substantial losses in the late 1970s (Fig. 12), and Chrysler had to be rescued with a $\$ 2$ billion bailout package. A new anti-regulation discourse gained prominence: "Government regulation came to be blamed for the nation's economic difficulties. (...) By the end of the decade, public debate was framed around the costs of regulation, and less and less was heard about its benefits" [39] (p. 90). Fearing unemployment, the United Auto Workers abandoned the antismog coalition and joined the car industry in lobbying for delays in emission standards [40].

Policy-makers. Policy makers gave more prominence to economic support than to air pollution. In 1977, American automakers challenged policy makers through illegal actions (they produced cars that did not meet the 1978 air pollution standards). Congress gave in and postponed the standards instead of shutting down factories [40]. HC and CO standards were pushed back to 1980 and 1981, respectively, while the $\mathrm{NO}_{\mathrm{x}}$ standard was relaxed (from 0.4 to $1.0 \mathrm{~g} / \mathrm{mile}$ ) for 1981 cars [48].

The Reagan administration (since January 1981) was sympathetic to the industry's complaints and set up a Task Force for Regulatory Relief, which proposed to roll back more than 34 safety, emissions and fuel economy regulations [39,52]. Although the proposal was stopped by a public backlash, clean air regulations made no further progress until 1990 [36].

\subsubsection{Car industry issue responses}

Socio-cultural and political strategies. The economic problems emboldened the industry, which simply refused to comply with 1978 CAA standards. The industry also set up 'grassroots' campaigns to pressure congressmen and it mobilized supporters inside Congress to delay bills in hearings [40]. In 1979, "with the industry as a whole in crisis, industry officials approached the federal government for changes in virtually every aspect of public policy that affected them" [39] (p. 104).

Technological innovation strategies. The postponement of CAA standards led the industry to downscale R\&D efforts and patenting activity (Fig. 10). By then, automakers had developed the basic technology for three-way catalysts (TWC) [36], which simultaneously controlled emissions of $\mathrm{HC}, \mathrm{CO}$ and $\mathrm{NO}_{\mathrm{x}}$. Whereas previous catalytic devices were end-of-pipe innovations, the TWC entailed architectural innovations in the engine, based on electronic control, oxygen sensors, and feedback mechanisms, which were necessary to keep the air/fuel ratio within a narrow operational window [34,40]. In 1981, GM introduced a TWC system, which lowered emissions level by $96 \%$ for $\mathrm{CO}$ and $\mathrm{HC}$ and $76 \%$ for $\mathrm{NO}_{\mathrm{x}}$ [34].

Although TWC devices added another $\$ 250$ to car prices in 1981(Fig. 11), industry resistance was limited. One reason was that the industry had more time following the 1977 amendments and had already acquired relevant technical capabilities [34]. Another 
reason was that the industry learned that electronic controls developed for TWC could also be used for general engine improvements [48].

\subsubsection{Broader industry evolution}

\subsubsection{Broader industry contexts}

Institutional environment. Recall campaigns, quality problems, and safety problems (e.g. with GM's Vega and Ford's Pinto cars) continued to damage the reputation of American cars [47]. "After being regarded for decades as symbols of America's pride and prosperity, the companies were coming to be derided as callous corporations that had contempt for their customers" [44] (p. 60).

Task environment. Shrinking markets (Fig. 9) caused financial problems (Fig. 12). Cumulatively, the Big Three lost about $\$ 4.73$ billion between 1980 and 1982 (in current dollars) [45]. Market shares of the Big Three decreased from 84\% in 1977 to $72 \%$ in 1981, while Japanese imports grew from 9 to 17\% (Fig. 4). Consumers increasingly preferred Japanese cars because of higher quality, fuel efficiency, and lower price.

American automakers blamed the Japanese success on 'unfair' competition due to cheap Japanese labour and a strong dollar [45]. The American government accepted this problem framing and supported the industry with tax reliefs, relaxation of federal regulations, and financial aid. The government also pressured Japanese automakers into a ‘voluntary' agreement that restrained Japanese exports to America to 1.68 million cars between 1981 and 1984 [39]. Between 1984 and 1988 the economic tide turned for the better when the Big Three made record profits (Fig. 12).

4.5.2.2. Industry strategies and regime dimensions. In this period, the industry gained the upper hand with regard to institutional pressures around air pollution, safety, and fuel efficiency, and benefitted from political support measures. The industry continued to resist environmentalism, which was not included in its mission. The industry's belief system remained unchanged, namely that environmental innovations do not sell but increase costs. The greening process did not lead to full strategic reorientation. The technical changes were forced by law and spurred by external and internal competition. The technical knowledge base was altered through the incorporation of new competencies (in catalysts and electronic controls), and the technology forcing policies stimulated the American automakers to reengage with innovation, which received more strategic attention [41].

\section{Analysis}

\subsection{Pattern-matching of DILC - model and case study}

The case study showed that the greening of the car industry was a long and contested process that was played out on various dimensions. The case confirmed the notion that the greening process can be studied as an issue lifecycle, with air pollution pressure starting on the periphery of the industry, and gradually gathering pace (from concerns to activists to public opinion and policy). As institutional pressures built up, the issue encroached upon the industry and forced it to make adjustments in the industry regime. This section confronts the empirical periods with the ideal-type phase-model. Regarding the overall pattern, the case study had a relatively good match with the first three conceptual phases, but deviated from the fourth and fifth phase.

In the first period pressure came from civil society, as suggested by the model. The car industry largely ignored the smog problem, and denied its involvement. A small deviation from the phase-model was that early pressure came from citizen protests, newspapers (LA Times), and scientific research rather than from activists.

In the second period, new social movement organizations enacted pressure, together with public concerns following shock events. The industry responded by creating a collective organization (APF) to investigate the problem. Although the car industry acknowledged contributions, it delayed solutions by stressing the need for further investigations. It also created the Vehicle Combustion Products Committee, which secretly delayed technical progress. One deviation from the model is that there were early spillovers to policy makers who expressed concerns (symbolic action) and provided grants for scientific studies. Another deviation is that the industry investigated technical alternatives (e.g. Ford's early work on catalytic converters).

The third period was close to the predicted pattern in the sense that an organized social movement emerged, public opinion became more concerned, and spillovers occurred to policy makers, who began to introduce regulations. The industry changed position and favoured tackling the issue at the national level, where it used political and framing strategies to delay issue progress. Yet, automakers also made incremental engine improvements, and pursued some defensive hedging towards alternative solutions such as catalysts. A deviation from the model is that there were no spillovers to 'moral customers'.

The fourth period matched the model in the sense that strict regulations were introduced (1970 CAA), leading the industry to increase R\&D investments and patenting. Cracks appeared in the industry front as GM became a product champion for catalysts. These cracks benefitted implementation of the CAA, which might have suffered further delays if the industry had maintained a closed front. The technological jockeying for position was accompanied by collective strategies to delay issue progress, so that GM (and Ford) got more time to catch up with catalyst suppliers. But the fourth phase also deviated from the model in the sense that issue progression slowed down in the mid-1970s because public opinion pressure weakened, because competing issues came to the fore (oil shock, fuel efficiency, economic problems) and because the industry successfully counter-mobilized.

The fifth period also deviated from the predicted pattern, because policy and public opinion pressure further weakened. Furthermore, the industry only made some changes in technology and strategy, but there was no comprehensive reorientation in foundational beliefs and mission. Issue progression remained dormant until the 1990s. 
These findings reinforce our qualification that the DILC-model represents an ideal-type pattern from which real-world cases may deviate. Future empirical studies could form the basis for developing a broader typology of issue lifecycle patterns. In that respect, Bigelow et al. [28] propose some interesting ideas. Besides a 'normal path', they suggest that issue evolution may follow other patterns such as: a) halted path (issue progression stops because of weakening pressures and increased industry resistance, as in our case), b) skipped path (the issue accelerates and skips phases because of intense external pressure), c) recursive or cyclical path (the issue moves backwards and forwards between phases depending on varying strengths of external pressures and industry resistance). We would also like to add the possibility that issues can change meaning during their lifecycle (through new interpretations and framings), and thus change direction.

\subsection{Multi-dimensional struggles and industry strategies}

The case study showed that industry actors use multi-dimensional strategies and that these change throughout the issue lifecycle. Table 2 summarises the case findings to enrich the basic issue lifecycle logic (discussed in Section 2) and develop a more comprehensive picture of the various pressures and industry response strategies. The basic pattern is that, in early phases, industry actors formed a closed front (through APF and AMA), and employed defensive (mostly socio-cultural and political) strategies to protect the existing regime. As institutional pressures accumulated, industry actors gradually moved towards incremental technical innovation and some defensive hedging (exploration of alternatives). But a shift towards more pro-active strategies did not happen until period 4, when several developments aligned: a) tough regulations (1970 CAA), backed up by civil society pressure, changed the industry's frame conditions, b) regime outsiders (catalyst suppliers) and new entrants (foreign competitors such as Honda, Mazda, Mercedes-Benz) exerted competitive pressures on industry incumbents and provided information that helped reduce the information asymmetry between regulators and the industry, c) the closed industry-front began to crumble as individual firms adopted pro-active innovation strategies (GM acting as product champion for catalysts). The industry front closed again in the fifth period, when American car firms experienced serious economic problems, counter-mobilized and articulated an anti-regulation discourse. The opening and closing of an industry front thus appears to be a crucial mechanism in issue lifecycles and the greening of industry. We also observe that strategies do not remain strictly separated, but are fuzzier in the real-world. In particular, there were frequent spillovers between the industry's innovation activities and political strategies, e.g. signalling that regulations are not necessary because firms are already working on solutions.

\subsection{Multi-dimensional alignments between (internal) issue lifecycle and broader contexts}

Issue evolution cannot be fully understood by looking only at (internal) dialectic struggles. Because industry actors operate in multiple contexts, they also face other pressures from markets, civil society, and polity, which may accelerate or hinder issue lifecycles. In our case study the following positive alignments with field-level developments helped the issue forward:

- In the 1960s, the emergence of environmental consciousness was a broad cultural trend that strengthened public attention for air pollution. Earth Day 1 was the culmination of this trend, which created a favourable context for the 1970 CAA.

- In the mid-1960s, public concerns around car safety damaged the car industry's reputation, and strengthened the belief that the industry was not interested in public welfare and would only act if forced.

- Competitive struggles with foreign car companies influenced the regulatory battle, because the engine innovations and information strategies from new entrants undermined the American industry's claims that the 1970 CAA standards were unfeasible.

The case study also contained negative alignments which hindered issue progression:

- The 1973 oil shock created economic problems and stimulated interest in fuel efficiency, which overshadowed cultural and political attention for air pollution.

- In the late 1970 s, the industry used its economic problems to articulate an anti-regulation discourse that resonated with broader problems in the American economy. This discourse halted regulatory progress on air pollution.

These findings underline that an analysis of (internal) issue lifecycle dynamics should be complemented with an analysis of broader contexts and field-level developments. That is why we proposed our dialectic issue lifecycle model with an embedded view of industries.

More generally, the case study confirms the importance of analysing the institutional environment. The mid-1960s and early 1970s formed a 'tipping point' in the case study, because acceleration in the air pollution issue coincided with wider institutional changes (rising environmentalism, activist culture, public outrage over anti-innovation agreements and safety scandals) that damaged the industry's legitimacy and created vulnerability by diminishing support from the wider public and policy makers. Apart from the specific air pollution issue, this period was characterized by a wider struggle about social responsibilities of the car industry and an increasing gap between societal and political expectations and industry attitudes. The car industry was out of touch with broader societal and political developments. Our case study demonstrated the importance of this maladjustment with the institutional environment. 
Table 2

Summary of issue pressures and industry responses in the case study.

\begin{tabular}{|c|c|c|c|c|c|c|c|c|}
\hline & \multicolumn{4}{|c|}{ Societal pressures } & \multicolumn{4}{|l|}{ Industry responses } \\
\hline & \multicolumn{2}{|c|}{ Institutional environment } & \multicolumn{2}{|l|}{ Task environment } & \multicolumn{2}{|l|}{ Institutional environment } & \multicolumn{2}{|c|}{ Task environment } \\
\hline & Civil society & Policy makers & Consumers & Regime outsiders & Socio-cultural & Political & $\begin{array}{l}\text { Economic } \\
\text { positioning }\end{array}$ & Technological \\
\hline $\begin{array}{l}1943 \\
-1953\end{array}$ & $\begin{array}{l}\text { Citizen } \\
\text { concerns. LA- } \\
\text { Times reports, } \\
\text { scientific } \\
\text { reports }\end{array}$ & $\begin{array}{l}\text { Symbolic } \\
\text { discourse and } \\
\text { ineffective } \\
\text { policies in CA }\end{array}$ & Unconcerned & Not yet involved & $\begin{array}{l}\text { Denial that cars } \\
\text { caused LA-smog }\end{array}$ & $\begin{array}{l}\text { None connected } \\
\text { to the issue }\end{array}$ & $\begin{array}{l}\text { None } \\
\text { connected } \\
\text { to the issue }\end{array}$ & $\begin{array}{l}\text { None connected } \\
\text { to the issue }\end{array}$ \\
\hline \multicolumn{5}{|c|}{ Problem-framing: refineries and automobiles are key sources of pollution } & \multicolumn{4}{|c|}{ Issue is contested ('more research needed') } \\
\hline $\begin{array}{c}1953- \\
1960\end{array}$ & $\begin{array}{l}\text { Formation of } \\
\text { anti-smog } \\
\text { groups (SOS). } \\
\text { Moderate rise } \\
\text { in public } \\
\text { attention. }\end{array}$ & $\begin{array}{l}\text { First regulation } \\
\text { in CA; debates } \\
\text { at federal level }\end{array}$ & Unconcerned & $\begin{array}{l}\text { Catalyst suppliers acquire } \\
\text { first patents }\end{array}$ & $\begin{array}{l}\text { Framing strategy } \\
\text { ('CA is special case') Promises } \\
\text { of solutions (AMA joint-venture) }\end{array}$ & $\begin{array}{l}\text { Divide-and-rule strategy } \\
\text { between state and } \\
\text { federal levels. }\end{array}$ & $\begin{array}{l}\text { None } \\
\text { connected } \\
\text { to the issue }\end{array}$ & $\begin{array}{l}\text { Incremental } \\
\text { engine } \\
\text { innovation via } \\
\text { AMA Vehicle } \\
\text { Combustion } \\
\text { Products } \\
\text { Committee } \\
\text { (creation of } \\
\text { closed-front). } \\
\text { Ford explores } \\
\text { catalysts. }\end{array}$ \\
\hline \multicolumn{5}{|c|}{ More dramatic problem framing (health risk) } & \multicolumn{4}{|c|}{ Industry accepts problem, and claims to work on solutions via AMA } \\
\hline $\begin{array}{l}1960- \\
1970\end{array}$ & $\begin{array}{l}\text { Rising public } \\
\text { concerns, } \\
\text { because of } \\
\text { alignment } \\
\text { with } \\
\text { environmental } \\
\text { movement, }\end{array}$ & $\begin{array}{l}\text { Increasing } \\
\text { debates and } \\
\text { regulations at } \\
\text { state and } \\
\text { federal level, } \\
\text { because of } \\
\text { increasing }\end{array}$ & $\begin{array}{l}\text { No issue spillover to } \\
\text { consumer preferences. }\end{array}$ & $\begin{array}{l}\text { Suppliers offer catalysts, } \\
\text { but car firms } \\
\text { do not adopt. }\end{array}$ & $\begin{array}{l}\text { Framing strategies } \\
\text { (claim that solutions will be } \\
\text { expensive). }\end{array}$ & $\begin{array}{l}\text { Dual track strategy: a) lobbying } \\
\text { against regulation, b) when } \\
\text { regulation could not be prevented, } \\
\text { industry lobbied for federal } \\
\text { standards (to prevent state-level } \\
\text { fragmentation) }\end{array}$ & $\begin{array}{l}\text { None } \\
\text { connected } \\
\text { to the issue }\end{array}$ & $\begin{array}{l}\text { Implementation } \\
\text { of incremental } \\
\text { innovations (e.g. } \\
\text { PCV valves). } \\
\text { Exploration of } \\
\text { more radical } \\
\text { alternatives }\end{array}$ \\
\hline
\end{tabular}


to tough regulation (1970 CAA)

\section{0- Peak in public Contested Consule (1970 CAA) na}

1977 attention, implementation affected by air pollution.

followed by of CAA

decline as regulation.

attention Debate

shifts to becomes very

competing technical. Fuel

issues economy

concerns lead

to delays in

deadlines.

Regulatory uncertainty ends with (weaker) CAA amendments of 1977

\begin{tabular}{|c|c|c|c|}
\hline $\begin{array}{r}1977- \\
1985\end{array}$ & $\begin{array}{l}\text { Decreasing } \\
\text { public } \\
\text { pressure. But } \\
\text { environmental }\end{array}$ & $\begin{array}{l}\text { Industry } \\
\text { protection } \\
\text { trumps air } \\
\text { pollution }\end{array}$ & New market established by law. \\
\hline
\end{tabular}

pressure. But trumps air

movement has collution

development.

Suppliers improve

catalysts. Foreign makers

offer less polluting cars.

stakeholder. 1981

Air pollution stalled but environmentalism institutionalized.
Decreasing legitimacy and reputation. Cracks in closed industry front

Divergence between collective Political fightback to delay CAA discourse (which resist issue) and and get compliance concessions. individual discourses (GM Top executive involved in advertises catalysts). lobbying.

house)

GM breaks Shift from

ranks and incremental

becomes engine

'catalytic innovation to

converter catalyst

champion' technology.

(jockeying 'Innovation race'

for first with suppliers.

advantages).

Industry front strengthens because of economic problems.

Industry aligns behind anti- $\quad$ Refusal to comply. Use economic Catalysts TWC leads to

in

tation of bad economic situation. delays.

architect

feconomic engine design.

positioning

strategy.

Partial regime reorientation: new regulations, strategies, and technical knowledge, but unchanged beliefs and mission. 


\subsection{Regime inertia}

We also analysed the industry regime to provide deeper explanations of inertia and industry resistance. The industry's financially-oriented mission created inertia in the 1950s and 1960s because it led to a downscaling of product and process innovation. This strategy was reinforced by the belief that consumers wanted styling, chrome and big cars rather than quality and technical progress. The industry's resistance against air pollution control innovations was influenced by this broader regime characteristic.

Furthermore, the belief that the industry played a crucial role in society made it difficult for automakers to appreciate societal changes in the mid-1960s. Because increased demands for public interests (such as air pollution and safety) conflicted with their perceived mission and threatened their identity, they felt besieged and responded antagonistically. The resistance to air pollution thus had an ideological component, namely the protection of managerial autonomy against meddlesome policy makers and activists. The confidence in their own importance also led them to underestimate Japanese competition, which they initially ridiculed. They failed to appreciate that Japanese firms were redefining competitive dimensions, drawing on their strengths in engineering creativity, quality, durability, workmanship, and production efficiency.

\section{Conclusions and discussion}

This article contributes to the greening of industry literature by developing a Dialectic Issue LifeCycle (DILC) model. Our model goes beyond lists of factors by providing a 'big picture' perspective that incorporates material dimensions (markets, profits, competition) and subjective dimensions (beliefs, interpretations, mission). It goes beyond stage models of the early 'greening' literature, because it allows issues to stop or move backwards to earlier phases. It also incorporates suggestions from the recent greening of industry literature such as addressing contestation and struggle, multi-dimensionality, and organizational fieldlevel analysis. The case study had a good match with the five-stage DILC-model, but also some deviations. Case study findings were used to inductively enrich the model with types of strategies and interactions. The case study also supported our claim that an analysis of corporate greening should not only look at the focal environmental issue, but also pay attention to broader contexts (cultural trends, outside competitors, market pressure, profits/losses, political climate, competing issues).

What are broader implications for sustainability transitions and for the greening of industry with regard to persistent environmental problems (see also [63], this issue, for a conceptual discussion of 'persistent problems') such as climate change? One implication is that low-carbon industrial transformation is likely to be a long and contested process on political, cultural, economic and technical dimensions. Because such sustainability transitions threaten core capabilities and vested interests, industry resistance is likely to be more intense than in our case, where core capabilities remained intact (catalyst innovation required additional knowledge but did not destroy existing capabilities).

Another implication, based on the case, is that expert warning from scientists may lead to policy debates, investigations and committees (as in the 1960s), but tend to be insufficient to trigger tough policy action. The latter seems more likely when policy makers face strong demand from public opinion (as with air pollution around 1970). In that respect, it is worth noting that air pollution problems were local and visible, while climate change is more diffuse, global and difficult to perceive by the public. Public mobilization may therefore be more difficult for climate change than for air pollution.

Thirdly, speculatively applying the DILC-model to the car industry, we suggest that the industry is currently in phase 3. The 1990s can be seen as phase 1, with the industry downplaying climate change (via the Global Climate Coalition). The late 1990s can be seen as phase 2 with automakers agreeing (in 1998) with the European Commission on 'voluntary' $\mathrm{CO}_{2}$ emission reduction targets and implementing incremental innovations (e.g. diesel engines, direct fuel injection, variable valve actuation). Since 2005 we may have entered phase 3, with automakers becoming more serious about alternative technologies. This was stimulated by the unexpected success of the Toyota Prius, which led to an innovation race in hybrid-electric cars and new expectations about battery-electric vehicles. A small group of 'moral customers' forms an early market niche for these low-carbon technologies. The contemporary challenge is to move to phase 4, in which climate change transforms the economic task environment. That could occur through changes in mainstream consumer preferences (for which there are presently few signs) or through policy changes in economic frame conditions (taxes, subsidies, stricter regulations). Present greenhouse gas (GHG) policies, however, are too weak to convince incumbent industries to fully commit to green alternatives: "The emerging GHG regime is simply not up to the task of a radical restructuring of energy and transportation markets. (...) While the momentum of this fragmented multi-facetted regime is clearly gathering pace, there is not yet a firm regulatory or economic incentive for firms to adopt radical changes in their strategies" [15] (p. 436-437).

Fourthly, the climate change issue can also stop progressing or move back to earlier stages. Certain actors, for instance, attempted to reopen the science base (and thus return to phase 1 ) by playing on 'climate gate'. ${ }^{12}$ The failure of the 2009 Copenhagen summit has (re)created uncertainties about the global political will to introduce tough regulations (thus hindering a move to phase 4).

Still, the orientations, technology strategies, and beliefs of car industry actors are presently 'greener' than they were in 1990. So, there is movement in the right direction, although the journey ahead is still long and probably filled with unexpected twists and turns. The dialectic issue lifecycle model aims to help understand that journey.

\footnotetext{
12 Climate gate refers to the leaked emails (November 2009) from climate researchers at the University of East Anglia, which in the eyes of climate sceptics showed tampering with the evidence.
} 


\section{Acknowledgements}

We thank Adrian Smith, Andy Stirling, Bruno Turnheim, Joe Tidd, Peter Wells, Carlota Perez, Michael Hopkins, three anonymous reviewers, and the special issue editors for their comments on previous versions of the paper. This work has been supported by an ERC grant (No. 204246).

\section{References}

[1] K. Fischer, J. Schot, Environmental Strategies for Industry: International Perspectives on Research Needs and Policy Implications in, Island Press, Washington (DC), 1993.

[2] N. Roome, Sustainability Strategies for Industry: The Future of Corporate Practice, in, Island Press, Washington (DC), 1998.

[3] M.E. Porter, C. Van der Linde, Green and competitive: ending the stalemate, Harv. Bus. Rev. 73 (1995) 120-134.

[4] S. Ambec, P. Lanoie, Does it pay to be green? A systematic overview, Acad. Manag. Perspect. 22 (2008) 45-62.

[5] R. Orsato, Competitive environmental strategies: when does it pay to be green? Calif. Manag. Rev. 48 (2006) 127-143.

[6] P. Bansal, K. Roth, Why companies go green: a model of ecological responsiveness in the UK and Japan, Acad. Manag. J. 43 (2000) 717-736.

[7] D. Fuchs, D. Mazmanian, The greening of industry: needs of the field business strategy and the environment, Bus. Strateg. Environ. 7 (1998) $193-203$.

[8] I. Henriques, P. Sadorsky, The determinants of an environmentally responsive firm: An empirical approach, J. Environ. Econ. Manag. 30 (1996) 381-395.

[9] N. Roome, Developing environmental management strategies, Bus. Strateg. Environ. 1 (1992) 11-24.

[10] P. Winsemius, U. Guntram, Responding to the environmental challenge, Bus. Horiz. (1992) 12-20.

[11] A. Ghobadian, H. Viney, J. Liu, P. James, Extending linear approaches to mapping corporate environmental behaviour', Bus. Strateg. Environ. 7 (1998) $13-23$.

[12] A. Schaefer, B. Harvey, Stage models of corporate 'greening': a critical evaluation, Bus. Strateg. Environ. 7 (1998) 109-123.

[13] T.J. Kallio, P. Nordberg, The evolution of organizations and natural environment discourse: some critical remarks, Organ. Environ. 19 (2006) 439-4457.

[14] A.J. Hoffman, Linking organizational and field-level analyses: the diffusion of corporate environmental practice, Organ. Environ. 14 (2001) $133-156$.

[15] C.A. Jones, D.L. Levy, North American business strategies towards climate change, Eur. Manag. J. 25 (2007) 428-440.

[16] A.J. Hoffman, M. Ventresca, Organizations, Policy and the Natural Environment: Institutional and Strategic Perspectives, Stanford University Press, Stanford (CA), 2002.

[17] W.R. Scott, Institutions and Organizations Sage publications, Thousand Oaks, CA, 1995.

[18] F.W. Geels, A triple embeddedness framework of industrial change: understanding the co-evolution of industry with markets, civil society and politics, Paper submitted (under review) to Research Policy, 2012.

[19] M.E. Porter, Competitive Strategy: Techniques for Analyzing Industries and Competitors, Free Press, New York, 1980.

[20] A. Giddens, The Constitution of Society: Outline of the Theory of Structuration, University of California Press, Berkeley, 1984.

[21] A. Hillman, M. Hitt, Corporate political strategy formulation: a model of approach, participation, and strategy decisions, Acad. Manag. Rev. 24 (1999) 825-842.

[22] M. Lounsbury, M.A. Glynn, Cultural entrepreneurship: stories, legitimacy, and the acquisition of resources, Strateg. Manag. J. 22 (2001) 545-564.

[23] R.R. Nelson, S.G. Winter, An Evolutionary Theory of Economic Change, Belknap Press, Cambridge (MA), 1982.

[24] R. Buchholz, Public Policy Issues for Management, Prentice-Hall, Englewood Cliffs (NJ), 1988.

[25] J.E. Post, Corporate Behavior and Social Change, Reston, Reston (VA), 1978.

[26] J.F. Mahon, S.A. Waddock, Strategic issues management: an integration of issue life cycle perspectives, Bus. Soc. 31 (1992) 19-32.

[27] K. Lamertz, M. Martens, P. Heugens, Issue evolution: a symbolic interactionist perspective, Corp. Reput. Rev. 6 (2003) 82-93.

[28] B. Bigelow, L. Fahey, J.F. Mahon, A typology of issue evolution, Bus. Soc. 32 (1993) 18-29.

[29] R.H. Miles, K.S. Cameron, Coffin Nails and Corporate Strategies, Prentice-Hall, Englewood Cliffs (NJ), 1982.

[30] B. Elzen, F.W. Geels, C. Leeuwis, B. Van Mierlo, Normative contestation in transitions 'in the making': animal welfare concerns and system innovation in pig husbandry (1970-2008), Res. Policy 40 (2011) 263-275.

[31] B.P. Pashigian, Environmental regulation: whose self-interests are being protected? Econ. Inq. 23 (1985) 551-584.

[32] F.W. Geels, B. Verhees, Cultural legitimacy and framing struggles in innovation journeys: a cultural-performative perspective and a case study of Dutch nuclear energy (1945-1986), Technol. Forecast. Soc. Chang. 78 (2011) 910-930.

[33] C.C. Ragin, Turning the tables: how case-oriented research challenges variables-oriented research, Comp. Soc. Res. 16 (1997) 24-42.

[34] R.J. Mondt, Cleaner Cars: The History and Technology of Emission Control Since the 1960s, SAE, Warrendale, PA, 2000.

[35] G.R. Lester, The Development of Automotive Exhaust Catalysts, in: B.H. Davis, J.W.P. Hettinger (Eds.), Heterogeneous Catalysis: Selected American Histories, American Chemical Society, 1983.

[36] J. Lee, F. Veloso, D. Hounshell, E. Rubin, Forcing technological change: a case of automobile emissions control technology development in the US, Technovation 30 (2010) 249-264.

[37] J. Nil, J. Tiessen, Policy, Time, and Technological Competition: Lean Burn Engine Versus Catalytic Converter, in: C. Sartorius, S. Zundel (Eds.), Time Strategies, Innovation and Environmental Policy, Edward Elgar, Cheltenham, 2005, pp. 131-152.

[38] J.E. Krier, E. Ursin, Pollution and policy: a case essay on California and Federal experience with motor vehicle air pollution, 1940-1975, University of California Press, Berkeley, 1977.

[39] S. Luger, Corporate Power, American Democracy, and the Automobile Industry, Cambridge University Press, Cambridge, 2000.

[40] J. Doyle, Taken for a Ride: Detroit's Big Three and the Politics of Pollution, Four Walls Eight Windows, New York and London, 2000.

[41] W.J. Abernathy, K.B. Clark, A.M. Kantrow, Industrial Renaissance: Producing a Competitive Future for America, Basic Books, New York, 1983.

[42] J.J. Flink, The Automobile Age, The MIT Press, Cambridge (MA), 1990.

[43] D. Halberstam, The Reckoning, Avon Books, New York, 1986.

[44] P. Ingrassia, Crash Course: The American Automobile Industry's Road from Glory to Disaster, Random House, New York, 2010.

[45] P. Ingrassia, J.B. White, Comeback: The Fall and Rise of the American Automobile Industry, Simon \& Schuster, New York, 1995.

[46] L.J. White, The automobile industry since 1945, Harvard University Press, Cambridge (MA), 1971.

[47] B. Yates, The decline and fall of the American automobile industry, Vintage Books, New York, 1983.

[48] D. Gerard, L. Lave, Implementing technology-forcing policies: the 1970 Clean Air Act amendments and the introduction of advanced automotive emissions controls in the United States, Technol. Forecast. Soc. Chang. 72 (2005) 761-778.

[49] G.A. Gonzales, Local growth coalitions and air pollution controls: the ecological modernisation of the US in historical perspective, Environ. Polit. 11 (2002) $121-144$

[50] R.F. Freeland, The Struggle for Control of the Modern Corporation: Organizational Change at General Motors, 1924-1970, Cambridge University Press, Cambridge, 2001.

[51] C. Jacobs, W. Kelly, Smogtown: the lung-burning history of pollution in Los Angeles, The Overlook Press, Woodstock, 2008.

[52] R. Dunlap, Trends in Public Opinion Towards Environmental Issues: 1965-1990, in: R. Dunlap, A. Mertig (Eds.), American environmentalism: the US environmental movement, 1970-1990, Taylor \& Francis, Philadelphia, 1992, pp. 89-116.

[53] USDHEW, No laughing matter: the cartoonist focuses on Air Pollution, USDHEW, Washington (DC), 1966.

[54] C. Bailey, Congress and Air Pollution, Manchester University Press, Manchester, 1998.

[55] E. Elliott, B. Ackerman, J. Millian, Toward a theory of statutory evolution: the federalization of environmental law, J. Law Econ. Organ. 1 (1985) 313-339.

[56] D.E. Stikkers, Octane and the environment, Sci. Total. Environ. 299 (2002) 37-56.

[57] Science, auto pollution: EPA worrying that the catalyst may backfire, Science 182 (1973) 368-371. 
[58] USEPA, Environmental Investments: The Cost of a Clean Environment, USEPA, Washington (DC), 1990.

[59] C. Hyde, Riding the Roller Coaster: A History of the Chrysler Corporation, Wayne State University Press, Detroit, 2003.

[60] I. Studer-Noguez, Ford and the global strategies of multinationals: the North American auto industry, Routledge, London, 2001.

[61] Wall Street Journal, GM Unveils Plan to Phase In New Device For Cleaner Air on All Its Autos by 1982, in: Wall Street Journal, 1977.

[62] Wall Street Journal, GM Loses Patent Suit It Filed Against Toyota, in: Wall Street Journal, 1979.

[63] T.J. Schuitmaker, Identifying and unravelling persistent problems, Technological Forecasting and Social Change 79 (2012) $1021-1031$ (this issue).

Caetano C.R. Penna (1980) is DPhil candidate at SPRU (Science Policy Research Unit), at the University of Sussex (UK). He received his MA in Technological Governance from Tallinn University of Technology (Estonia) and now studies the co-evolution of technologies and industries in relation to societal issues. His current work focuses on the car industry and combines quantitative and qualitative methods. Caetano draws on fields like evolutionary economics, business and society, innovation management, and public policy studies. He is supervised by Professor Frank W. Geels.

Frank W. Geels (1971) is Professor at SPRU (Science Policy Research Unit), at the University of Sussex (UK). He is interested in socio-technical transitions, the emergence of new technologies, co-evolution of technology and society, industrial change and corporate strategy, sustainable development, and the role of cultural dynamics and expectations. He is well-known for his theoretical work on the multi-level perspective and strategic niche management, and performed a dozen of historical case studies to test and elaborate these theories. His work is inter-disciplinary and mobilises insights from science and technology studies, evolutionary economics, business studies, (neo)institutional theory and sociology. 